\title{
Climate impact on airborne particulate matter concentrations in California using seven year analysis periods
}

\author{
A. Mahmud ${ }^{1}$, M. Hixson ${ }^{1}$, J. Hu' ${ }^{2}$, Z. Zhao ${ }^{2}$, S.-H. Chen ${ }^{2}$, and M. J. Kleeman ${ }^{1}$ \\ ${ }^{1}$ Dept. of Civil and Environmental Engineering, University of California, Davis, One Shields Avenue, Davis, CA 95616, USA \\ ${ }^{2}$ Dept. of Land, Air, and Water Resources, University of California at Davis, One Shields Ave, Davis, CA 95616, USA
}

Received: 21 December 2009 - Published in Atmos. Chem. Phys. Discuss.: 5 February 2010

Revised: 11 October 2010 - Accepted: 6 November 2010 - Published: 25 November 2010

\begin{abstract}
The effect of global climate change on the annual average concentration of fine particulate matter $\left(\mathrm{PM}_{2.5}\right)$ in California was studied using a climate-air quality modeling system composed of global through regional models. Output from the NCAR/DOE Parallel Climate Model (PCM) generated under the "business as usual" global emissions scenario was downscaled using the Weather Research and Forecasting (WRF) model followed by air quality simulations using the UCD/CIT airshed model. The system represents major atmospheric processes acting on gas and particle phase species including meteorological effects on emissions, advection, dispersion, chemical reaction rates, gas-particle conversion, and dry/wet deposition. The air quality simulations were carried out for the entire state of California with a resolution of 8$\mathrm{km}$ for the years 2000-2006 (present climate with present emissions) and 2047-2053 (future climate with present emissions). Each of these 7-year analysis periods was analyzed using a total of 1008 simulated days to span a climatologically relevant time period with a practical computational burden. The 7-year windows were chosen to properly account for annual variability with the added benefit that the air quality predictions under the present climate could be compared to actual measurements. The climate-air quality modeling system successfully predicted the spatial pattern of present climate $\mathrm{PM}_{2.5}$ concentrations in California but the absolute magnitude of the annual average $\mathrm{PM}_{2.5}$ concentrations were under-predicted by $\sim 4-39 \%$ in the major air basins. The majority of this under-prediction was caused by excess ventilation predicted by PCM-WRF that should be present to the same degree in the current and future time periods so that the net bias introduced into the comparison is minimized.
\end{abstract}

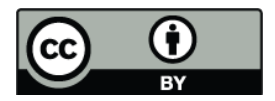

Correspondence to: M. J. Kleeman (mjkleeman@ucdavis.edu)
Surface temperature, relative humidity $(\mathrm{RH})$, rain rate, and wind speed were predicted to increase in the future climate while the ultra violet (UV) radiation was predicted to decrease in major urban areas in the San Joaquin Valley (SJV) and South Coast Air Basin (SoCAB). These changes lead to a predicted decrease in $\mathrm{PM}_{2.5}$ mass concentrations of $\sim 0.3-0.7 \mu \mathrm{g} \mathrm{m}^{-3}$ in the southern portion of the SJV and $\sim 0.3-1.1 \mu \mathrm{g} \mathrm{m}^{-3}$ along coastal regions of California including the heavily populated San Francisco Bay Area and the SoCAB surrounding Los Angeles. Annual average $\mathrm{PM}_{2.5}$ concentrations were predicted to increase at certain locations within the SJV and the Sacramento Valley (SV) due to the effects of climate change, but a corresponding analysis of the annual variability showed that these predictions are not statistically significant (i.e. the choice of a different 7-year period could produce a different outcome for these regions). Overall, virtually no region in California outside of coastal + central Los Angeles, and a small region around the port of Oakland in the San Francisco Bay Area experienced a statistically significant change in annual average $\mathrm{PM}_{2.5}$ concentrations due to the effects of climate change in the present study.

The present study employs the highest spatial resolution $(8 \mathrm{~km})$ and the longest analysis windows (7 years) of any climate-air quality analysis conducted for California to date, but the results still have some degree of uncertainty. Most significantly, GCM calculations have inherent uncertainty that is not fully represented in the current study since a single GCM was used as the starting point for all calculations. The PCM results used in the current study predicted greater wintertime increases in air temperature over the Pacific Ocean than over land, further motivating comparison to other GCM results. Ensembles of GCM results are usually employed to build confidence in climate calculations. The current results provide a first data-point for the climate-air quality analysis that simultaneously employ the

Published by Copernicus Publications on behalf of the European Geosciences Union. 
fine spatial resolution and long time scales needed to capture the behavior of climate- $\mathrm{PM}_{2.5}$ interactions in California. Future downscaling studies should follow up with a full ensemble of GCMs as their starting point, and include aerosol feedback effects on local meteorology.

\section{Introduction}

Exposure to elevated concentrations of airborne particles with aerodynamic diameter less than $2.5 \mu \mathrm{m}\left(\mathrm{PM}_{2.5}\right)$ has serious health consequences (see for example, Pope, 2000). The National Ambient Air Quality Standard for annualaverage $\mathrm{PM}_{2.5}$ is currently $15 \mu \mathrm{g} \mathrm{m}^{-3}$ and the more stringent California State Air Quality Standard for annual-average $\mathrm{PM}_{2.5}$ is currently $12 \mu \mathrm{g} \mathrm{m}^{-3}$. Despite the adoption of a more stringent state standard, annual average $\mathrm{PM}_{2.5}$ concentrations measured in California's San Joaquin Valley (SJV) $\left(21.5 \mu \mathrm{g} \mathrm{m}^{-3}\right)$ and South Coast Air Basin (SoCAB) $\left(19.7 \mu \mathrm{g} \mathrm{m}^{-3}\right)$ were the highest in the nation during the years 2007-2008. Some estimates predict that more than 18000 California residents die prematurely each year due to air pollution (Tran et al., 2008). Meteorological parameters including temperature, precipitation, clouds, atmospheric water vapor, boundary layer height, wind speed, and wind direction influence the atmospheric chemistry and transport processes that determine $\mathrm{PM}_{2.5}$ concentrations (see for example, Aw and Kleeman, 2003; Kleeman, 2008; Sillman and Samson, 1995). Climate change will modify weather patterns in California with unknown consequences for $\mathrm{PM}_{2.5}$ concentrations.

The effect of global climate on regional $\mathrm{PM}_{2.5}$ concentrations can be studied using a dynamic downscaling approach where Global Climate Models (GCMs) provide initial and boundary conditions for Regional Climate Models (RCMs) with subsequent analysis using regional chemical transport models. California has several unique features that make this type of detailed analysis challenging. California's topographic features transition abruptly between mountains, valleys, deserts, lakes and oceans over distances of 10's of $\mathrm{km}$. Emissions patterns in California also change quickly over small spatial scales due to the complex arrangement of residential, commercial, industrial, agricultural, and natural landuse types. Intricate meteorological features that strongly influence air pollution concentrations such as the land-sea breeze system and mountain-valley flows must also be modeled using high spatial resolution. Regional air quality studies in California are usually carried out at spatial scales finer than $10 \mathrm{~km}$ to resolve these features. Long time periods must also be considered when studying climate-air quality interactions in California. Natural annual variation in meteorology such as the El-Niño Southern Oscillation (ENSO) has a strong effect on air quality. The period of the ENSO cycle in recent decades has been 3-8 years suggesting that air quality analysis must be carried out over a similar time scale in order to be climatologically relevant. The combined need for fine spatial scales and long simulation times results in a computationally challenging analysis for climate-air quality interactions in California.

Several recent studies have examined the effects of global climate change on regional air quality across the entire United States including California (see for example, Avise et al., 2009; Chen et al., 2009; Dawson et al., 2009; Hogrefe et al., 2004; Jacobson, 2008; Liao et al., 2009; Tagaris et al., 2009, 2007). The GCMs employed in the studies to date include the Goddard Institute for Space Studies (GISS) GCM (Russell et al., 1995), the NCAR/DOE Parallel Climate Model (PCM) (Washington et al., 2000), and the Stanford GATOR-GCMOM model (Jacobson, 2008). Most of the regional climate analysis was conducted using the fifth generation Penn State/NCAR Mesoscale Model (MM5) (Grell et al., 1994) although the GATOR-GCMOM model provides a unified framework from global to regional scales. Of those studies that compared $\mathrm{PM}_{2.5}$ concentrations in present and future climates with present emissions, Tagaris et al. (2009) simulated air quality for the entire United States using $36 \mathrm{~km}$ resolution for the years 2001 and 2050. The results of their study indicate that that the annual average $\mathrm{PM}_{2.5}$ concentration in some parts of California is likely to decrease by $\sim 1.5 \mu \mathrm{g} \mathrm{m}^{-3}$ in the future due to the effects of climate change alone under the A1B emissions scenario. Avise et al. (2009) also conducted a climate-air quality study for the entire United States using $36 \mathrm{~km}$ resolution but they focused their analysis on a single month (July) in the years 1990-1999 and 2045-2054. Results were averaged within the administrative regions defined by the United States Environmental Protection Agency (USEPA). Avise et al. (2009) predicted that 24-h average concentrations of $\mathrm{PM}_{2.5}$ mass, $\mathrm{PM}_{2.5}$ sulfate, $\mathrm{PM}_{2.5}$ nitrate, and $\mathrm{PM}_{2.5}$ ammonium for EPA's Region 9 (containing California) would decrease by $\sim 0.4 \mu \mathrm{g} \mathrm{m}^{-3}$, $\sim 0.1 \mathrm{~g} \mathrm{~m}^{-3}, \sim 0.1 \mu \mathrm{g} \mathrm{m}^{-3}, \sim 0.1 \mu \mathrm{g} \mathrm{m}^{-3}$, respectively, due to the effects of climate change alone. Dawson et al. (2009) modeled the climate effects on 24-h average total mass and speciated $\mathrm{PM}_{2.5}$ concentrations for the eastern United States under the A2 emissions scenario. In this study, the authors used $36-\mathrm{km}$ resolution and modeled January and July in 5 present years (1990s) and 5 future years (2050s) to report that on average the total mass and speciated $\mathrm{PM}_{2.5}$ concentrations are likely to decrease in January due to increased precipitation and increase in July due to decreased ventilation in the future. More recently, the direct impact of $\mathrm{CO}_{2}$ concentrations domes around major cities has been analyzed to identify slight $\mathrm{PM}_{2.5}$ concentrations increases (Jacobson, 2010) but this study does not address the effects of global climate change on pollutant concentrations.

None of the previous studies for the entire United States have simultaneously used spatial resolution finer than $10 \mathrm{~km}$ and analysis times longer than 3 years to determine how climate change will influence the annual average $\mathrm{PM}_{2.5}$ 
concentration in California. A recent study has been performed in Europe at this resolution (Halenka et al., 2010), but this does not provide information for California - the most heavily polluted region in the United States. The current study applies a dynamic downscaling approach with 8$\mathrm{km}$ spatial resolution during 7 years of current climate and 7 years of future climate to study climate-air quality interactions in California. The 7-year analysis period during the current climate is long enough to allow for a meaningful comparison between simulated vs. measured $\mathrm{PM}_{2.5}$ concentrations. To the best of our knowledge, this comparison is the most rigorous evaluation of a climate-air quality modeling system ever conducted. The 7-year analysis windows also contain enough data to support a statistical analysis of annual variability so that confidence intervals can be calculated for the differences between present vs. future conditions. The results of the current study reduce the uncertainty of likely climate impacts on annual-average $\mathrm{PM}_{2.5}$ concentrations in California at the regional scale.

\section{Methods}

Figure 1 shows a schematic diagram of the regional climateair quality modeling system employed in this study. The regional climate is simulated by dynamically downscaling output from the Parallel Climate Model (PCM) using the Weather Research and Forecasting (WRF) model, and the air quality is simulated using the latest generation of the UCD/CIT air quality model for the entire state of California. A detailed description of the modeling system is provided below.

PCM is a Global Climate Model (GCM) that was developed at the National Center for Atmospheric Research (NCAR) (Washington et al., 2000). The PCM model predicts meteorological variables only - it is not a chemical transport model. The parent PCM dataset utilized in this study was available in $2.8^{\circ}(\sim 240-\mathrm{km}) \times 2.8^{\circ}(\sim 310-\mathrm{km})$ horizontal resolution with 18 hybrid vertical layers from ground to $\sim 4 \mathrm{hPa}$. More recent applications of GCMs have increased the horizontal and vertical resolution of the calculations, but this task was delegated to the regional climate model in the current study. The PCM output was generated over a continuous period from 1995-2099 under the "business as usual" (BAU-B06.44) global emissions scenario. The original BAU emissions scenario was developed by Dai et al. (2001a, b). The 20th century emissions were generated with observation-based greenhouse gases, sulfate aerosol, solar, and volcanic forcings. The 21 st century emissions were projected based on development of world economies. The concentration of $\mathrm{CO}_{2}$ was set to increase by $1 \%$ per year under this scenario. The concentration of $\mathrm{SO}_{2}$ was set to increase with growing world economies in early part of the century, but decrease in the later part of the century because of the increasing capability to control $\mathrm{SO}_{2}$ emissions worldwide. Concentrations of $\mathrm{CH}_{4}, \mathrm{~N}_{2} \mathrm{O}$ and other trace green-

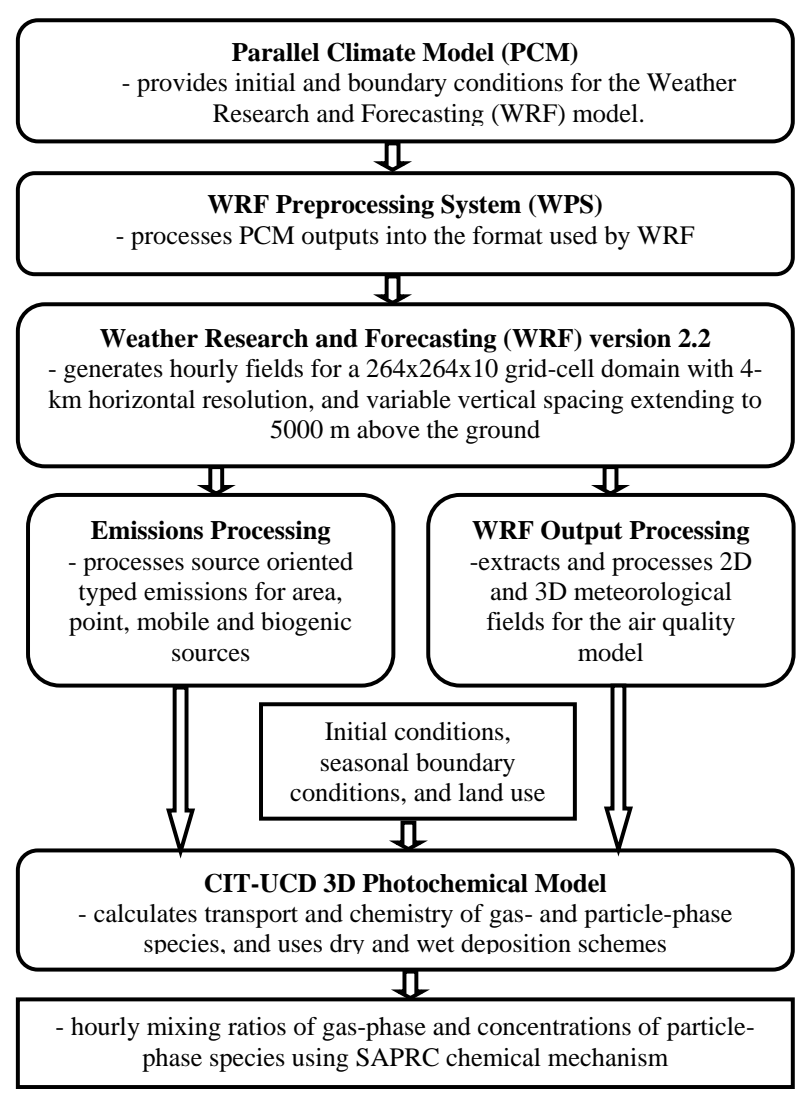

Fig. 1. Flow Chart of the climate downscaling and air quality modeling systems.

house gases (GHGs), and halocarbons in the atmosphere also accounted for future development with an overall increase in radiative forcing (see Dai et al., 2001a for detail). PCM output was obtained for a 7-year period in the present-day climate (2000-2006) and a 7-year period in the future climate (2047-2053). Seven year windows were selected to account for the effects of El Niño Southern Oscillation (ENSO) events and the intra-annual variability in the climate data that would have different implications in the final air quality results (see for example, Aw and Kleeman, 2003).

The PCM output was processed through the WRF Preprocessing System (WPS) in preparation for regional downscaling. Version 2.2 of the WRF model (Skamarock, 2004) was utilized to generate the regional climate data in this study. All of the WRF simulations were carried out using an optimized configuration of the modeling system for California (Zhao et al., 2010a, b). The optimization process tested six different configurations of WRF for conditions in central California. The best agreement with measured meteorological parameters was produced by the Yonsei University (YSU) planetary boundary layer (PBL) scheme (Hong et al., 2006), Grell-Devenyi cumulus parameterization scheme (Grell and Devenyi, 2002), WRF single-momentum 6-class (WSM6) microphysics scheme (Hong et al., 2004), Rapid Radiation 
Transfer Model (RRTM) long-wave scheme (Mlawer et al., 1997), Dudhia short-wave radiation scheme (Dudhia, 1989), and the Dudhia thermal diffusion land surface scheme. Notably, use of land surface schemes that explicitly consider soil moisture yielded considerably degraded performance for ambient relative humidity in California. The lack of soil moisture feedback disconnects the hydrology cycle from the air quality system other than the direct washout of pollutants during precipitation events. It would be highly desirable to construct a land-surface scheme that properly represents soil moisture in California so that these feedback effects could be studied in this region. The development, testing, and application of a new soil moisture scheme are beyond the scope of the current study.

The WRF simulations carried out in the current study used a three-domain 1-way nesting technique, where the coarse grid output provided initial and lateral boundary conditions for the fine grid simulations with horizontal resolutions of $36-\mathrm{km}, 12-\mathrm{km}$, and 4-km, respectively. Meteorological fields with $4-\mathrm{km}$ resolution were generated for a domain with $264 \times 264$ grid cells in the horizontal plane and 10-vertical layers extending to a height of $5000 \mathrm{~m}$ above the ground. The heights of the vertical layers in WRF were matched with those of the air-quality model such that the model used finer vertical resolutions near the surface. All of the variables were saved on the A-grid (i.e. in the center of a grid-cell) except for the u- and v-components of wind speed, which were staggered using the Arakawa C-grid (i.e. on the face center of each grid-cell). The native $\mathrm{C}$-grid output was retained for the wind field in order to achieve better accuracy in the air quality transport calculations. The gridded WRF output was averaged over each 60-min simulation period for every simulated day. A total of nine periods were simulated for each year that each consisted of 17 -days followed by 25 -days that were not simulated. The first simulation day of each year was set to be 1 January. This approach captures an unbiased sample of predicted meteorology and air quality across the full seven year period that reflects both seasonal variation and annual variability while still keeping the analysis time to a reasonable level.

Past studies have shown that fine-downscaling using mesoscale meteorological models like WRF enhances small-scale meteorological solutions but does not significantly alter regional average behavior (Leung et al., 2004; Liang et al., 2006). The WRF downscaling is initialized by the PCM output and then constrained by the PCM boundary conditions, and so they resolve the fine-scale details associated with the PCM results. It is not necessary to simulate the full 54-year period (2000-2053) at high resolution using WRF in order to study the effects within shorter time intervals. Downscaling the entire period would require a tremendous computational burden without changing the outcome. Likewise, the air quality simulations require only a $\sim 4$-day initialization period since atmospheric chemistry is constrained quite strongly by the emissions and meteorology.
Finer grid resolution provides a better description of smallscale meteorological dynamics such as sea-land breezes and orographical winds during regional meteorological modeling, but this resolution does not necessarily need to be retained in subsequent regional air quality modeling exercises. In the present study, the 4-km WRF meteorological fields were extracted and averaged to $8-\mathrm{km}$ resolution to generate inputs for the air quality modeling. The coarser resolution of the air quality model reflects a balance between accuracy and speed. Each 7-year study period involved 1008 simulation days over a domain composed of $131 \times 128 \times 10$ grid cells requiring approximately 45-days of real time to complete. Ying et al. (2008) showed that increasing the resolution of simulations in the Central Valley of California from 8-km to 4-km does not significantly improve accuracy but it increases the computational effort by a factor of 4 . A previous study carried out in Marseilles-Fos-Berre in the south of France has also found that beyond a certain point finer grid resolution does not necessarily yield better air quality predictions (Menut et al., 2005). The South Coast Air Quality Management District (SCAQMD) provides emissions inventories with $5-\mathrm{km}$ spatial resolution for the SoCAB and numerous previous air quality studies have been carried out at this scale (Griffin et al., 2002; Kleeman and Cass, 2001; Martien and Harley, 2006) without the perceived need to improve resolution to $4-\mathrm{km}$. The requirement for uniform grid spacing across the entire state of California combined with the balance between efficiency vs. accuracy produced the compromise of $8-\mathrm{km}$ grid resolution during the air quality modeling carried out in this study.

The initial conditions (ICs) of gas-phase and particlephase species were generated following the work of (Ying et al., 2008) and (Kleeman et al., 2007). Table 1 summarizes the domain average IC concentrations of major model species used in the current study as a function of season. The IC concentrations can be quantified within the UCD/CIT framework through the use of internal tracers. It was found that the influence of IC concentrations on air quality chemistry diminishes by the end of first 3-4-days in the current study. As a result, predicted concentrations from the first 4-days of each simulation period were disregarded in the calculations of periodic/annual average particulate matter (PM) concentrations. The boundary conditions (BCs) of various gas-phase and particle-phase species were adjusted for seasonal variability (Jaffe et al., 2005; Liang et al., 1998). The scaling for vertical boundary conditions was obtained from Ying et al. (2008), and boundary conditions at the top of the model domain were interpolated from the lateral boundary conditions in the top model layer. Table 2 summarizes the average BC concentrations of selected model species along the West Coast as used in the current study as a function of season. 
Table 1. Domain-averaged initial concentrations of major model gas and particle species at the surface.

\begin{tabular}{|c|c|c|c|c|c|}
\hline \multirow[b]{2}{*}{ Species } & \multirow[b]{2}{*}{ Unit } & \multicolumn{4}{|c|}{ Domain Average Concentration } \\
\hline & & $\begin{array}{r}\text { Winter } \\
\text { (DJF) }\end{array}$ & $\begin{array}{r}\text { Spring } \\
(\mathrm{MAM})\end{array}$ & $\begin{array}{r}\text { Summer } \\
\text { (JJA) }\end{array}$ & $\begin{array}{r}\text { Fall } \\
(\mathrm{SON})\end{array}$ \\
\hline Carbon monoxide (CO) & ppm & 0.2823 & 0.2823 & 0.2823 & 0.2823 \\
\hline Carbon dioxide $\left(\mathrm{CO}_{2}\right)$ & ppm & 332.00 & 332.00 & 332.00 & 332.00 \\
\hline Sulfur dioxide $\left(\mathrm{SO}_{2}\right)$ & ppm & 0.0020 & 0.0020 & 0.0020 & 0.0020 \\
\hline Nitrogen dioxide $\left(\mathrm{NO}_{2}\right)$ & ppm & 0.0046 & 0.0046 & 0.0046 & 0.0046 \\
\hline Nitric oxide (NO) & ppm & 0.0033 & 0.0033 & 0.0033 & 0.0033 \\
\hline Reactive hydro carbon (RHC) & ppm & 0.0513 & 0.0513 & 0.0513 & 0.0513 \\
\hline Ozone $\left(\mathrm{O}_{3}\right)$ & ppm & 0.0401 & 0.0401 & 0.0401 & 0.0401 \\
\hline Nitric acid $\left(\mathrm{HNO}_{3}\right)$ & ppm & 0.0010 & 0.0010 & 0.0010 & 0.0010 \\
\hline Ammonia $\left(\mathrm{NH}_{3}\right)$ & ppm & 0.0029 & 0.0029 & 0.0029 & 0.0029 \\
\hline Hydrochloric acid $(\mathrm{HCl})$ & ppm & 0.0010 & 0.0010 & 0.0010 & 0.0010 \\
\hline Formaldehyde (HCHO) & ppm & 0.0000 & 0.0000 & 0.0000 & 0.0000 \\
\hline Acetaldehyde $\left(\mathrm{CH}_{3} \mathrm{CHO}\right)$ & ppm & 0.0000 & 0.0000 & 0.0000 & 0.0000 \\
\hline Aldehydes (RCHO) & ppm & 0.0000 & 0.0000 & 0.0000 & 0.0000 \\
\hline Acetone (ACET) & ppm & 0.0006 & 0.0006 & 0.0006 & 0.0006 \\
\hline Methyl ethyl ketone (MEK) & ppm & 0.0000 & 0.0000 & 0.0000 & 0.0000 \\
\hline Methyl glyoxal (MGLY) & ppm & 0.0000 & 0.0000 & 0.0000 & 0.0000 \\
\hline Glyoxal (GLY) & ppm & 0.0000 & 0.0000 & 0.0000 & 0.0000 \\
\hline Peroxy acetyl nitrate (PAN) & ppm & 0.0003 & 0.0008 & 0.0008 & 0.0005 \\
\hline Hydrogen peroxide $\left(\mathrm{H}_{2} \mathrm{O}_{2}\right)$ & ppm & 0.005 & 0.005 & 0.005 & 0.005 \\
\hline Isoprene (ISO) & ppm & 0.0003 & 0.0003 & 0.0003 & 0.0003 \\
\hline Elemental carbon (EC) & $\mu \mathrm{g} \mathrm{m}^{-3}$ & 0.18 & 0.18 & 0.18 & 0.18 \\
\hline Organic carbon (OC) & $\mu \mathrm{g} \mathrm{m}^{-3}$ & 0.66 & 0.66 & 0.66 & 0.66 \\
\hline Nitrate $(\mathrm{N}(\mathrm{V}))$ & $\mu \mathrm{g} \mathrm{m}^{-3}$ & 0.36 & 0.36 & 0.36 & 0.36 \\
\hline Sulfate (S(VI)) & $\mu \mathrm{g} \mathrm{m}^{-3}$ & 0.45 & 0.45 & 0.45 & 0.45 \\
\hline Chloride $(\mathrm{Cl}(-1))$ & $\mu \mathrm{g} \mathrm{m}^{-3}$ & 0.19 & 0.19 & 0.19 & 0.19 \\
\hline Sodium (NA(1)) & $\mu \mathrm{g} \mathrm{m}^{-3}$ & 0.21 & 0.21 & 0.21 & 0.21 \\
\hline Ammonium (N(-III)) & $\mu \mathrm{g} \mathrm{m}^{-3}$ & 0.24 & 0.24 & 0.24 & 0.24 \\
\hline OTHER & $\mu \mathrm{g} \mathrm{m}^{-3}$ & 1.62 & 1.6 & 1.6 & 1.60 \\
\hline H2OPART & $\mu \mathrm{g} \mathrm{m}^{-3}$ & 0.891 & 0.89 & 0.89 & 0.89 \\
\hline
\end{tabular}

The base-case raw emissions inventories for the year 2000 were obtained from the California Air Resources Board (CARB) and the SCAQMD. Area source and point source emissions were used without modification in all simulations. On-road mobile source emissions were adjusted for the variation of meteorological conditions experienced during each simulation using CARB's Emissions Factors (EMFAC) model. EMFAC produces mobile emissions summaries for different pollutants and technology classes in 69 geographical locations spanning the entire state of California. EMFAC is also able to predict how temperature and humidity influence mobile source emissions of nitrogen oxides $\left(\mathrm{NO}_{\mathrm{x}}\right)$ and reactive hydrocarbons (RHCs). EMFAC results were generated for the base-case year 2000 emissions inventory and for the conditions predicted to occur within each of the 69 geographical regions at each simulated hour. The base-case year 2000 mobile source emissions were then scaled by the ratio of EMFAC ${ }^{\text {actual }} / \mathrm{EMFAC}^{\text {base-case }}$ for each pollutant of interest in each grid cell of the model domain. The net ef- fect of climate change averaged over the entire state of California was to increase $\mathrm{NO}_{\mathrm{x}}, \mathrm{RHC}$, and PM emissions from diesel engines by $\sim 2.5 \%$ and to decrease $\mathrm{NO}_{\mathrm{x}}, \mathrm{RHC}$, and $\mathrm{PM}$ emissions from gasoline engines by $\sim 2.1-3.7 \%$.

WRF predictions for hourly-averaged temperature and surface shortwave radiation in each grid cell were combined with the MODIS satellite data and fed into CARB's BEIGIS model to predict episode-specific biogenic volatile organic compound emissions. The net effect of climate change averaged over the entire state of California was to increase biogenic RHC emissions by $\sim 18 \%$.The adjusted mobile source emissions and the newly generated biogenic emissions were then processed with the remaining area and point sources to provide a source oriented model-ready gridded hourly emissions inventory.

The UCD/CIT air quality model employed in this study is based on the original CIT 3-D photochemical model (Harley et al., 1993; Mcrae et al., 1982) with updates to provide a source-oriented framework (see for example, Held et al., 
Table 2. Average boundary concentrations of various model gas and particle species concentrations along the western boundary of the modeling domain.

\begin{tabular}{|c|c|c|c|c|c|}
\hline \multirow[b]{2}{*}{ Species } & \multirow[b]{2}{*}{ Unit } & \multicolumn{4}{|c|}{ Domain Average Concentration } \\
\hline & & $\begin{array}{r}\text { Winter } \\
(\mathrm{DJF})\end{array}$ & $\begin{array}{r}\text { Spring } \\
(\mathrm{MAM})\end{array}$ & $\begin{array}{r}\text { Summer } \\
(\mathrm{JJA})\end{array}$ & $\begin{array}{r}\text { Fall } \\
(\mathrm{SON})\end{array}$ \\
\hline Carbon monoxide $(\mathrm{CO})$ & ppm & 0.4000 & 0.4000 & 0.4000 & 0.4000 \\
\hline Carbon dioxide $\left(\mathrm{CO}_{2}\right)$ & $\mathrm{ppm}$ & 332.0000 & 332.0000 & 332.0000 & 332.0000 \\
\hline Sulfur dioxide $\left(\mathrm{SO}_{2}\right)$ & ppm & 0.0010 & 0.0010 & 0.0010 & 0.0010 \\
\hline Nitrogen dioxide $\left(\mathrm{NO}_{2}\right)$ & ppm & 0.0010 & 0.0004 & 0.0003 & 0.0004 \\
\hline Nitric oxide (NO) & ppm & 0.0010 & 0.0004 & 0.0003 & 0.0004 \\
\hline Reactive hydro carbon (RHC) & ppm & 0.0069 & 0.0069 & 0.0069 & 0.0069 \\
\hline Ozone $\left(\mathrm{O}_{3}\right)$ & ppm & 0.0350 & 0.0400 & 0.0400 & 0.0350 \\
\hline Nitric acid $\left(\mathrm{HNO}_{3}\right)$ & ppm & 0.0007 & 0.0007 & 0.0007 & 0.0004 \\
\hline Ammonia $\left(\mathrm{NH}_{3}\right)$ & ppm & 0.0025 & 0.0025 & 0.0025 & 0.0025 \\
\hline Formaldehyde (HCHO) & ppm & 0.0015 & 0.0015 & 0.0015 & 0.0015 \\
\hline Acetaldehyde $\left(\mathrm{CH}_{3} \mathrm{CHO}\right)$ & ppm & 0.0020 & 0.0020 & 0.0020 & 0.0020 \\
\hline Aldehydes (RCHO) & ppm & 0.0014 & 0.0014 & 0.0014 & 0.0014 \\
\hline Acetone (ACET) & $\mathrm{ppm}$ & 0.0015 & 0.0015 & 0.0015 & 0.0015 \\
\hline Glyoxal (GLY) & $\mathrm{ppm}$ & 0.0002 & 0.0002 & 0.0002 & 0.0002 \\
\hline Peroxy acetyl nitrate (PAN) & ppm & 0.0005 & 0.0005 & 0.0005 & 0.0003 \\
\hline Isoprene (ISO) & ppm & 0.0000 & 0.0000 & 0.0000 & 0.000 \\
\hline Elemental carbon (EC) & $\mu \mathrm{g} \mathrm{m}^{-3}$ & 0.01 & 0.01 & 0.01 & 0.01 \\
\hline Organic carbon (OC) & $\mu \mathrm{g} \mathrm{m}^{-3}$ & 0.02 & 0.02 & 0.02 & 0.02 \\
\hline Nitrate $(\mathrm{N}(\mathrm{V}))$ & $\mu \mathrm{g} \mathrm{m}^{-3}$ & 0.04 & 0.03 & 0.03 & 0.03 \\
\hline Sulfate (S(VI)) & $\mu \mathrm{g} \mathrm{m}^{-3}$ & 0.05 & 0.05 & 0.05 & 0.05 \\
\hline Chloride $(\mathrm{Cl}(-1))$ & $\mu \mathrm{g} \mathrm{m}^{-3}$ & 0.06 & 0.06 & 0.06 & 0.06 \\
\hline Sodium (NA(1)) & $\mu \mathrm{g} \mathrm{m}^{-3}$ & 0.06 & 0.06 & 0.06 & 0.06 \\
\hline Ammonium (N(-III)) & $\mu \mathrm{g} \mathrm{m}^{-3}$ & 0.01 & 0.01 & 0.01 & 0.01 \\
\hline OTHER & $\mu \mathrm{g} \mathrm{m}^{-3}$ & 0.03 & 0.03 & 0.03 & 0.03 \\
\hline H2OPART & $\mu \mathrm{g} \mathrm{m}^{-3}$ & 1.47 & 0.35 & 1.09 & 0.65 \\
\hline
\end{tabular}

2004; Kleeman and Cass, 2001; Kleeman et al., 1997; Mysliwiec and Kleeman, 2002; Ying and Kleeman, 2003, 2006; Ying et al., 2008). Only those aspects of the UCD/CIT model that were updated during the current study are discussed here.

Previous studies (Byun, 1999; Hu et al., 2006; Lee et al., 2004; Odman and Russell, 2000; Sportisse et al., 2007) have found mass consistency errors when the meteorological model and the chemistry-transport model do not use the same grid system, the same interpolation strategies and/or the same transport algorithms. Hu et al. (2006) proved the existence of the mass consistency errors while using the MM5/CMAQ modeling system and recommended an effective way to overcome the problem by re-calculating the vertical wind velocity using the horizontal wind components and atmospheric density generated by the meteorology model. Calculation of vertical winds was therefore incorporated into the UCD/CIT modeling framework in the current study. The UCD/CIT model was also updated so that it could work with either prognostic wind fields (C-grid) or diagnostic wind fields (A-grid).
The computational burden of simulating air quality in a large domain over 2016-days motivated revisions to the approach for gas-particle transfer of inorganic species in the UCD/CIT model. The original approach for gas-particle conversion involved fully dynamic transfer of both acidic and basic species between the gas and particle phase, requiring many thousands of calls to the thermodynamics routines during each integration time step within each grid cell. The fully dynamic approach for gas-particle conversion was replaced by the approach proposed by (Jacobson, 2005) whereby acid gases are treated as fully dynamic species while ammonia is considered to be in equilibrium between the gas and particle phases. The original thermodynamic routines were based on the Aerosol Inorganic Module (AIM) developed by (Wexler and Seinfeld, 1992) with updates to correct coding errors and impose minimum water constrains to keep the solution in the continuum region (Clegg et al., 2008). The modified approach used in the present study replaces the AIM thermodynamics module with ISORROPIA II (Fountoukis and Nenes, 2007; Nenes et al., 1998) to calculate the vapor pressure of semi-volatile inorganic species above each particle surface. 
The combination of these changes increased the speed of the model calculations by roughly a factor of two with less than $10 \%$ difference in the final predicted concentrations of gasphase and particle-phase species.

Wet deposition calculations were added to the UCD/CIT model so that it could correctly predict removal rates for gases and particles during rain events. The wet deposition is calculated based on solutions to the differential rate equations describing the washout rate which depend on rain rates, rain-drop size distributions, and airborne particle size distributions (Loosmore and Cederwall, 2004). The gas-phase removal is calculated based on the rain rates and chemical composition of the gas-phase species (i.e., solubility). The rain drop size distribution was calculated as a function of total precipitation rate (Cerro et al., 1997).

The original version of the UCD/CIT model relied on independently generated emissions inventories for sea salt over ocean grid cells. The input data and correlations used to calculate sea salt emissions are relatively simple, and so the sea salt emissions algorithm was embedded directly within the UCD/CIT model in the present study. Sea salt emissions over the open ocean (Gong, 2003) and sea salt emissions in the surf zone (de Leeuw et al., 2000) were both predicted by this new module based on the surface wind speed. The net effect of climate change averaged all the ocean cells in the study domain was to decrease sea salt emissions by $\sim 12 \%$.

The UCD/CIT model includes major atmospheric processes acting on gas and particle phase species including meteorological effects on emissions, advection, dispersion, chemical reaction rates, gas-particle conversion, and dry/wet deposition. The model also includes the calculation of extinction of UV by airborne particles which modifies the photochemical reaction rates. However, the model does not include feedback mechanisms whereby emitted aerosols influence the temperature structure of the atmosphere or the formation of clouds. The UCD/CIT model also does not predict feedbacks to the stratospheric ozone layer. These issues act as a potential source of uncertainty in the final air quality results, but they should not change the overall conclusions of the study.

\section{Results}

Airborne particulate matter concentrations in California are strongly influenced by temperature, relative humidity, UV radiation, wind speed, and mixing height (Aw and Kleeman, 2003; Kleeman, 2008). It is instructive to examine the climate-induced changes to these meteorological variables over 7-year windows to gain greater insight into the processes that influence $\mathrm{PM}_{2.5}$ concentrations. Figure 2 shows the differences between the future (2047-2053) and presentday (2000-2006) averages for ground-level temperature, humidity, wind speed, precipitation, mixing height, and UV radiation. Figure $2 \mathrm{a}$ shows that the surface air tempera- ture is predicted to increase by $\sim 1.0-1.7^{\circ} \mathrm{C}$ over the $\mathrm{Pa}$ cific Ocean west of California and increase by $\sim 0.1$ to $1.3^{\circ} \mathrm{C}$ over California inland regions in the future years compared to the present-day. The predicted increase is slightly greater $\left(\sim 1.0^{\circ} \mathrm{C}\right)$ in large urban areas such as Los Angeles, Bakersfield, Fresno, San Francisco and Sacramento compared to rural and mountainous areas $\left(\sim 0.2-0.8^{\circ} \mathrm{C}\right)$.

The prediction of larger temperature increases over the ocean than over land is caused by large-scale features of the PCM simulation that drive the WRF model during the downscaling exercise. Future PCM predictions for air temperature $2 \mathrm{~m}$ above the surface increase more over the Pacific Ocean than over the California land mass during the months of December, January, and February. Much of this change is driven by the sea-surface temperature inherited from the PCM simulations and by an increased frequency of precipitation events over land during the winter months. These PCM temperature and precipitation patterns are consistent with the results produced by the Community Climate System Model (CCSM) operated under the SRES A2 emissions scenario. Although some GCMs may predict greater future temperature increase over land than over the ocean during winter months, the results of the PCM simulations used in the current study are a legitimate example of a relatively modern simulation of climate that contributes to the ensemble of results that have been produced by the scientific community to date. In contrast to the winter trends, both PCM and CCSM predict that air temperatures over land increase more than air temperatures over water during the summer months. Hotter temperatures generally encourage lower $\mathrm{PM}_{2.5}$ concentrations in California through the evaporation of ammonium nitrate aerosol (Kleeman, 2008). A downward bias in future surface temperature over land would produce an upward bias in predicted future $\mathrm{PM}_{2.5}$ concentrations.

The predicted change in future (2047-2053 vs. 20002006) relative humidity (RH) at the surface is shown in Fig. 2b. RH is predicted to decrease by $\sim 0.10-1.9 \%$ over the ocean as the air temperature warms because the amount of additional water vapor evaporated from the ocean surface does not keep pace with the additional capacity of the warmer atmosphere to hold water vapor. $\mathrm{RH}$ is predicted to increase by $\sim 0.2-4.4 \%$ over land as the moist air cools by $0.5-0.8^{\circ} \mathrm{C}$ reducing its capacity to hold water vapor. The SoCAB is predicted to experience the greatest increase in RH by as much as $4 \%$ compared to only $\sim 0.2-0.6 \%$ in the SJV in the future. Increasing RH encourages the partitioning of ammonium nitrate to the particle phase (Kleeman, 2008). Any upward bias in predicted $\mathrm{RH}$ would once again bias $\mathrm{PM}_{2.5}$ concentrations upwards.

Wind speed and mixing height are two of the most critical meteorological parameters for air pollution calculations since they determine the ventilation of fresh emissions away from the surface. Air pollution episodes in California are generally characterized by a stagnation period (low ventilation) lasting more than 2-days. Figure $2 \mathrm{c}$ shows that the 
(a) Temperature in ${ }^{\circ} \mathrm{C}$

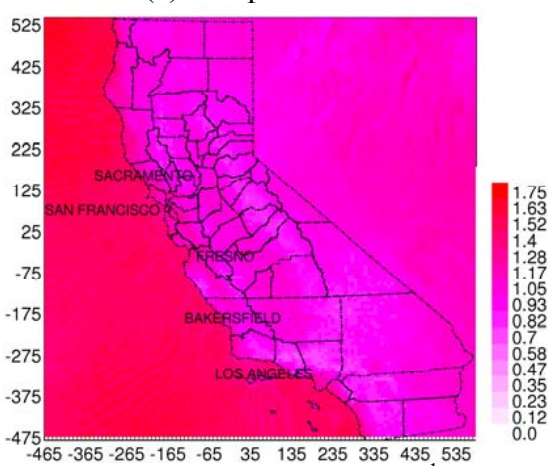

(c) Wind Speed in $\mathrm{ms}^{-1}$

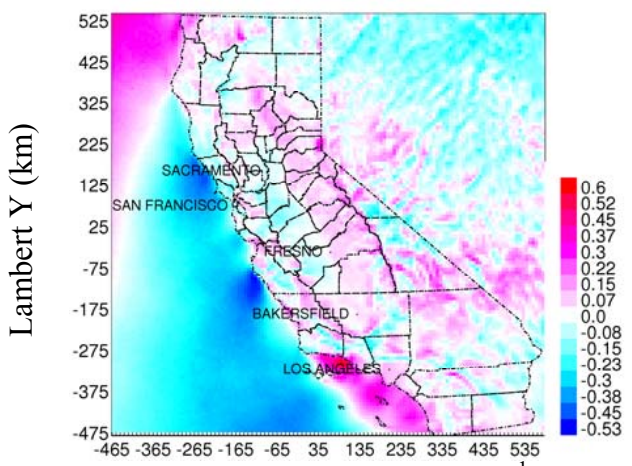

(e) Precipitation in $\mathrm{mmhr}^{-1}$

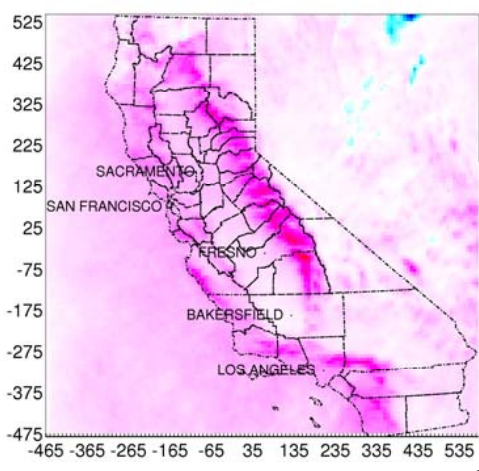

(b) Relative Humidity in \%

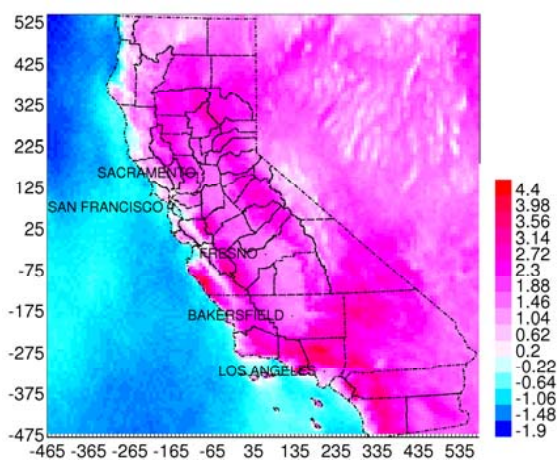

(d) Mixing Height in $\mathrm{m}$

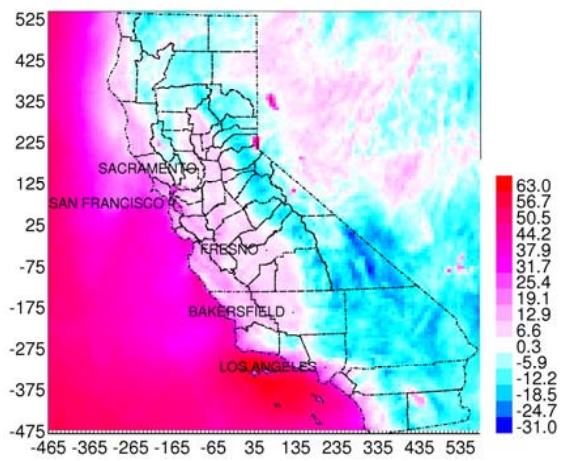

(f) Ultra Violate Radiation in \%

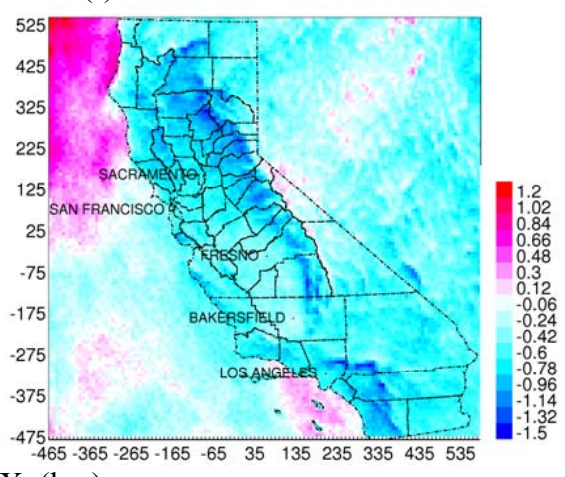

Lambert X (km)

Fig. 2. Panels (a-f) show changes in annual average values in meteorological parameters likely to occur due to climate change in the future (2047-2053) from the present-day (2000-2006).

future wind speed (2047-2053) is predicted to increase by as much as $\sim 0.3 \mathrm{~ms}^{-1}$ around Los Angeles in the SoCAB, and decrease by $\sim 0.1-0.2 \mathrm{~ms}^{-1}$ in some parts of the SJV, and the Sacramento Valley air basins relative to current years (20002006). These changes are important since average wind speed in these air basins are approximately $2.7 \mathrm{~ms}^{-1}$. The mixing height (planetary boundary layer) shown in Fig. 2d is predicted to increase by $\sim 20-25 \mathrm{~m}$ in the coastal areas but decrease by $\sim 25-30 \mathrm{~m}$ in the Sierra Nevada mountain range. The average future mixing height is predicted to increase by $\sim 6 \mathrm{~m}$ in the SJV and by $\sim 20 \mathrm{~m}$ in the lower part of the SoCAB. All of these changes are small compared to the base-case average mixing height of $\sim 600 \mathrm{~m}$ and so they have little effect on pollutant concentrations. The major driver for changes to future air pollution concentrations associated with ventilation is the changes to wind speed illustrated in Fig. 2c.

Figure $2 \mathrm{e}$ shows that the average future (2047-2053) precipitation rate is predicted to increase by $\sim 0.3 \mathrm{~mm} \mathrm{~h}^{-1}$ in the Sierras and some areas in the SoCAB relative to current years (2000-2006). Precipitation in the SJV is predicted to increase by $\sim 0.01-0.04 \mathrm{~mm} \mathrm{~h}^{-1}$ in the future $(\sim 80 \%$ increase over current levels). The increased rate reflects the increased humidity in the atmosphere resulting in greater precipitation rates during rain events and a general lengthening of the rainy season. Future SJV precipitation rates increased by $\sim 40 \%$ in the current rainy season (DJF) but increased by $\sim 240 \%$ 
(a) Total Mass

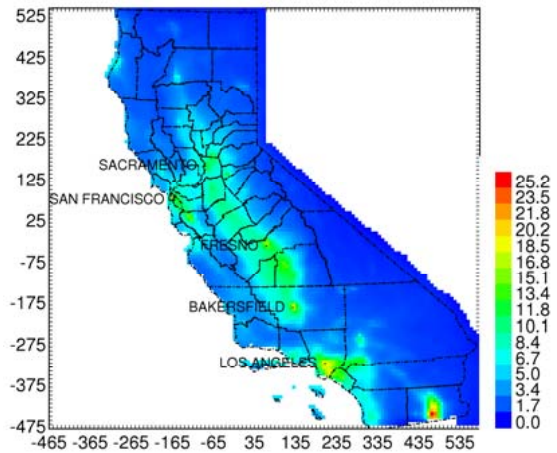

(c) $\mathrm{OC}$

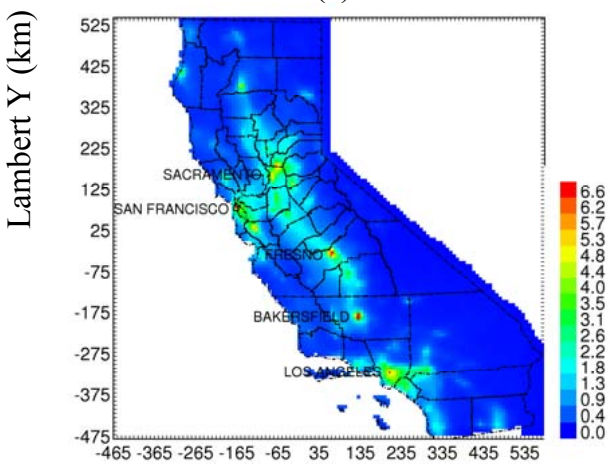

(e) Ammonium

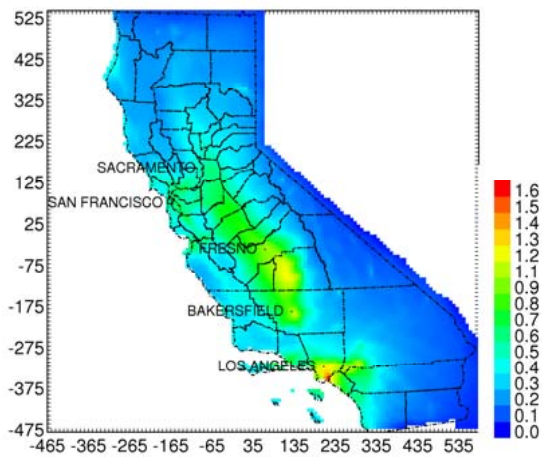

(b) EC

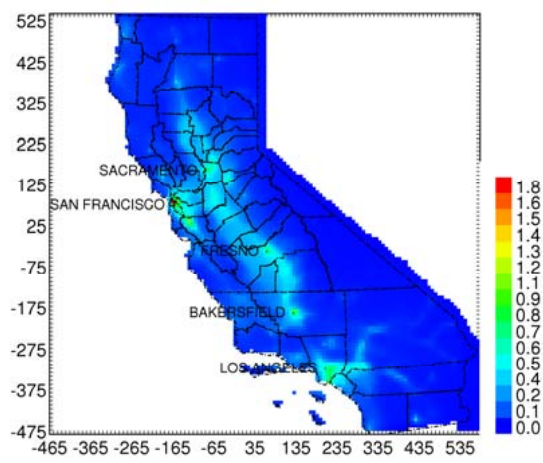

(d) Nitrate

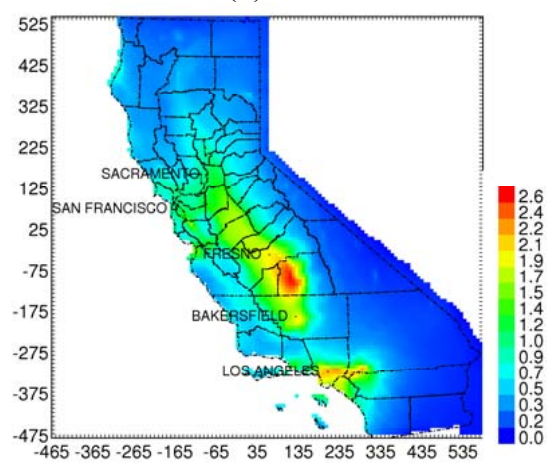

(f) Sulfate

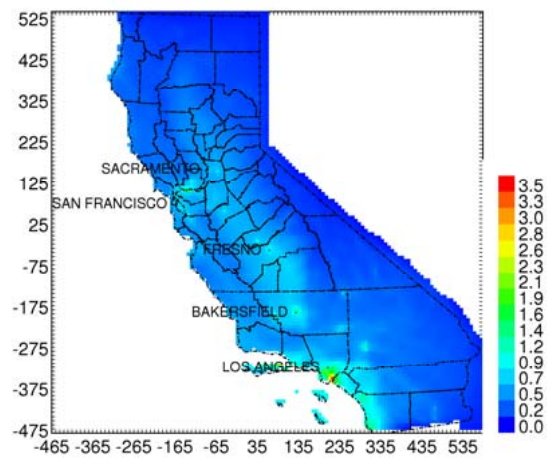

Lambert X $(\mathrm{km})$

Fig. 3. Annual average $\mathrm{PM}_{2.5}$ concentrations in CA for the present-day (2000-2006) (a) total mass, (b) elemental carbon, (c) organic carbon, (d) nitrate, (e) ammonium, and (f) sulfate.

in the months before and after the traditional rainy season (September, October, March, May). Increased precipitation enhances the wet deposition of pollutants leading to reduced atmospheric concentrations.

Figure 2f illustrates that future (2047-2053) UV radiation is predicted to decrease by $\sim 1.0-1.5 \%$ in the Sierras, and by $\sim 0.4-0.5 \%$ in the SJV and SoCAB. UV flux decreases as cloud cover increases and so the trend in UV radiation is consistent with the pattern of precipitation rates in the future, i.e. the UV radiation is likely to decrease as precipitation rates increase. UV radiation drives photochemical chemical reactions in the atmosphere leading to increased concentrations of secondary particulate matter. Reduced UV will re- duce the production of secondary PM. Further details of the effects of climate on air pollution meteorology in California are discussed by Zhao et al. (2010a, b).

Figure 3a shows the present-day (2000-2006) annual average concentrations of $\mathrm{PM}_{2.5}$ mass for the entire state of California to illustrate current pollutant spatial patterns. Higher $\mathrm{PM}_{2.5}$ concentrations $\left(>\sim 15 \mu \mathrm{g} \mathrm{m}^{-3}\right)$ are predicted around the urban centers such as Los Angeles, Bakersfield, Fresno, San Francisco and Sacramento because primary particulate emissions sources are concentrated in these regions. Elevated total $\mathrm{PM}_{2.5}$ concentrations $\left(>\sim 10 \mu \mathrm{g} \mathrm{m}^{-3}\right)$ are also predicted along the major transportation routes in the SJV and SoCAB. The highest $\mathrm{PM}_{2.5}$ total mass concentrations are predicted in 
the vicinity of El Centro in the southeast portion of the domain due to the influence of windblown dust.

Figures $3 \mathrm{~b}-\mathrm{f}$ show the contribution to $\mathrm{PM}_{2.5}$ total mass from elemental carbon (EC), organic carbon (OC), nitrate $(\mathrm{N}(\mathrm{V}))$, ammonium $(\mathrm{N}(-\mathrm{III})$ ) and sulfate $(\mathrm{S}(\mathrm{VI}))$ concentrations, respectively. Primary particulate matter components such as EC and OC account for approximately $\sim 50 \%$ of the total $\mathrm{PM}_{2.5}$ mass concentrations in California during the present-day (2000-2006) simulations. Maximum annual average EC concentrations of $\sim 0.5-1.0 \mu \mathrm{g} \mathrm{m}^{-3}$ are found in the major urban areas and along the major transportation routes as shown in Fig. 3b. The highest EC concentration of $\sim 1.8 \mu \mathrm{g} \mathrm{m}^{-3}$ was predicted around the port of Oakland in the San Francisco Bay Area under the present-day climate.

Predicted annual average OC concentrations are also higher around the major sources of primary emissions in the domain (Fig. 3c). Maximum annual average OC concentrations in the range of $\sim 5.0-6.6 \mu \mathrm{g} \mathrm{m}^{-3}$ are predicted in the San Joaquin and Sacramento Valleys near major urban areas, while predicted OC concentrations in the SoCAB are in the range of $\sim 3.0-5.0 \mu \mathrm{g} \mathrm{m}^{-3}$.

Figure $3 \mathrm{~d}$ shows the predicted annual average concentrations of $\mathrm{PM}_{2.5}$ nitrate in California. Nitrate accounts for $\sim 12 \%$ of the annual average $\mathrm{PM}_{2.5}$ mass over broad segments of the state. Predicted nitrate concentrations range from $\sim 1.2-2.6 \mu \mathrm{g} \mathrm{m}^{-3}$ in the SJV to $\sim 1.2-2.0 \mu \mathrm{g} \mathrm{m}^{-3}$ in the SoCAB. The majority of the particulate nitrate is neutralized by ammonium ion and so it is not surprising that the pattern of annual-average ammonium ion concentration (Fig. 3e) appears similar to the pattern of nitrate concentration. The highest annual average nitrate concentration $\left(\sim 2.6 \mu \mathrm{g} \mathrm{m}^{-3}\right)$ and corresponding ammonium ion concentration $\left(\sim 1.3 \mu \mathrm{g} \mathrm{m}^{-3}\right)$ were predicted in the region between Fresno and Bakersfield where gas-phase ammonia emissions from agricultural sources are highest. Predicted ammonium nitrate concentrations had a strong seasonal dependence with concentrations in the winter season (DJF) $\sim 3$ times larger than the summer (JJA).

Predicted annual average concentrations of sulfate (S(VI)) were $\sim<1.0 \mu \mathrm{g} \mathrm{m}^{-3}$ in the SJV but as high as $\sim 1.0-3.5 \mu \mathrm{g} \mathrm{m}^{-3}$ in the SoCAB. Higher annual average concentrations of sulfate $\left(\sim 2.0 \mu \mathrm{g} \mathrm{m}^{-3}\right)$ were also found along the coastal areas of the SoCAB. This spatial pattern gives strong clues that shipping emissions are the dominant source of sulfate aerosol in the present day simulations.

Climate-air quality predictions are often presented with little verification that the base-case modeling system is able to reproduce present-day air quality concentrations over multiyear periods. Climate-air quality modeling systems that use GCM inputs downscaled to regional scales cannot resolve individual air pollution events but the multi-year average concentrations predicted by these systems should ideally match the multi-year average measurements in each region of interest. Previous studies have evaluated the performance of the UCD/CIT 3-D photochemical airshed model driven by ob- served meteorological fields (Ying et al., 2008). The present study is among the first to evaluate model performance over a climatologically relevant time-frame (7-year averages) using prognostic meteorology produced by a GCM.

Figure 4 shows comparisons between the predicted and observed concentrations of primary and secondary $\mathrm{PM}_{2.5}$ components averaged between the years 2000-2006 at representative locations in California's most heavily populated air basins. The Central Los Angeles (CELA) site is located in the SoCAB. The Modesto (M14), Visalia (VCS), Fresno (FSF) and San Jose (SJ4) sites are situated in the greater SJV, and the Sacramento (S13) site is in the SV air basin. For each site, 24-h average measured concentrations of the $\mathrm{PM}_{2.5}$ total mass and the major chemical components that contribute to $\mathrm{PM}_{2.5}$ mass were obtained from CARB. The corresponding predicted concentrations were then extracted for the presentday (2000-2006) air quality simulations. Daily average concentrations were used to calculate mean values and standard deviations over the 7-year period. Panels (a-c) in Fig. 4 show the comparisons between the predicted and observed concentrations of $\mathrm{PM}_{2.5}$ total mass, $\mathrm{PM}_{2.5}$ elemental carbon (EC), and $\mathrm{PM}_{2.5}$ organic carbon (OC). Annual average $\mathrm{PM}_{2.5}$ total mass concentrations above $\sim 20.0 \pm 2.0 \mu \mathrm{g} \mathrm{m}^{-3}$ were measured in both the SoCAB and the SJV. Predicted annual average $\mathrm{PM}_{2.5}$ total mass concentrations $\left(\sim 13-18 \mu \mathrm{g} \mathrm{m}^{-3}\right)$ were 4-39\% lower than measured values, with consistent underpredictions at all sites. Measured maximum $\mathrm{PM}_{2.5}$ total mass concentrations in the SoCAB and the SJV were in the range $\sim 15-25 \mu \mathrm{g} \mathrm{m}^{-3}$, but the corresponding predicted concentrations were $\sim 15-53 \%$ lower during the present-day conditions. Model performance was relatively better at San Jose (SJ4) and Sacramento (S13) compared to other sites. In general, the variation between measured $\mathrm{PM}_{2.5}$ concentrations at different sites is greater than the variation between predicted $\mathrm{PM}_{2.5}$ concentrations at those same locations (compare the height of the average bars between locations in Fig. 4a). In contrast, the time variation of the predicted $\mathrm{PM}_{2.5}$ concentrations at the same site can be greater than, equivalent to, or less than the time variation of measured $\mathrm{PM}_{2.5}$ concentrations at that same site (compare the size of the uncertainty bars at each location in Fig. 4a).

Figure $4 \mathrm{~b}$ illustrates that present-day (2000-2006) predictions for EC concentrations are $64 \%$ lower than measured values at central Los Angeles and 12\%-39\% lower than measured values at all other sites except San Jose where they agree well with measurements. EC is a primary pollutant and so wide-spread under-predictions suggest a systematic bias in emission rates, removal rates, and/or ventilation (wind speed $\times$ mixing height). The fundamental equations and input data files used to represent emissions and removal rates have been validated during numerous retrospective modeling studies that used diagnostic wind fields (Held et al., 2005; Ying et al., 2008) and so it seems likely that the ventilation rates predicted by the prognostic PCM-WRF meteorological fields are slightly over-predicted. Recent studies 
(a) Total Mass

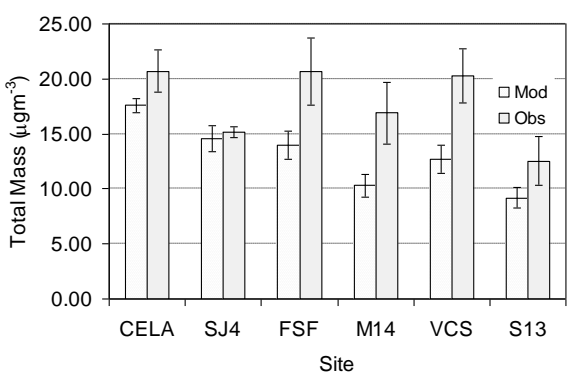

(c) Organic Carbon

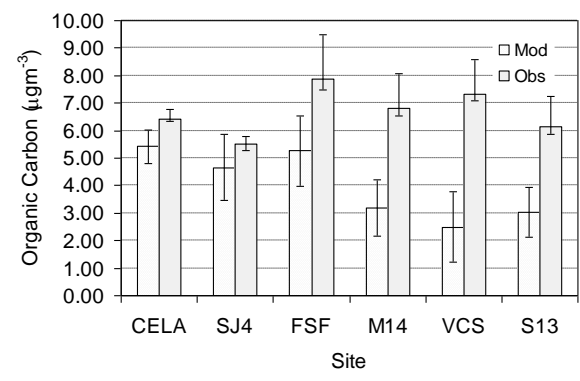

(e) Ammonium

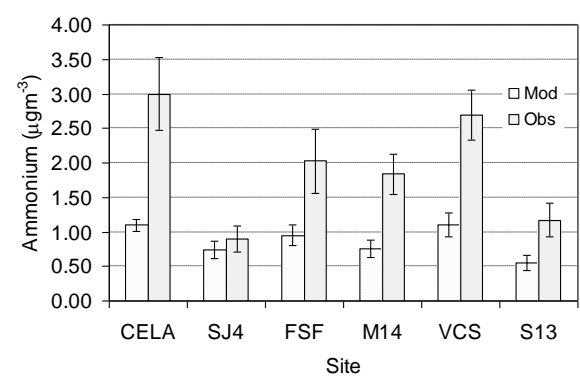

(b) Elemental Carbon

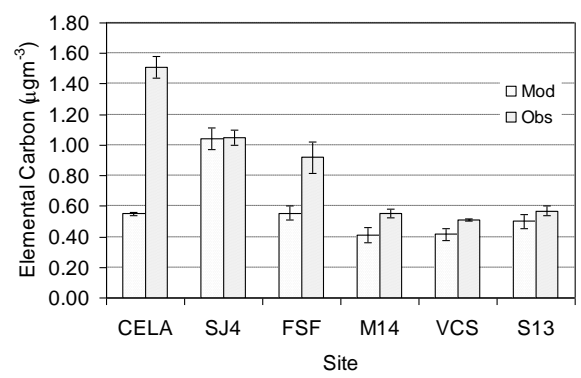

(d) Nitrate

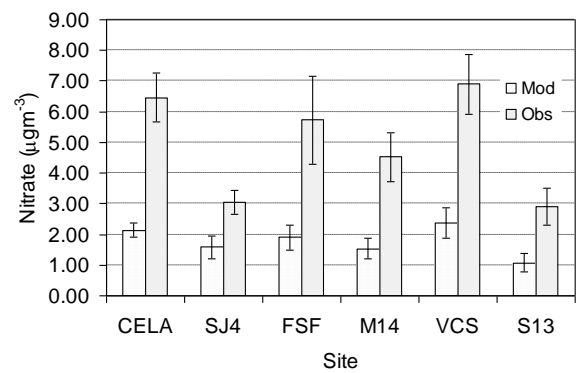

(f) Sulfate

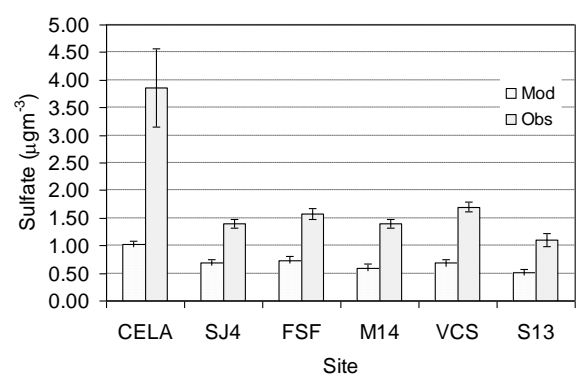

Fig. 4. Comparison between modeled and observed 7-year average $\mathrm{PM}_{2.5}$ (a) total mass, (b) elemental carbon, (c) organic carbon, (d) nitrate, (e) ammonium, and (f) sulfate concentrations at different sites in California: (1) CELA-central Los Angeles North Main St, (2) SJ4-San Jose 4th St, (3) FSF-Fresno 1st St, (4) M14-Modesto 14th St, (5) VCS-Visalia Church St, and (6) S13-Sacramento T St.

confirm that prognostic meteorological fields provide greater ventilation than diagnostic meteorological fields in central California (Hu et al., 2009). A zero-order approximation of the air pollution system would predict that concentration $(C)\left(\mu \mathrm{g} \mathrm{m}^{-3}\right)=$ emissions rate $(E)\left(\mu \mathrm{g} \mathrm{m}^{-3}\right) /$ ventilation rate $(V)\left(\mathrm{m}^{3} \mathrm{~h}^{-1}\right)$. From this simplified relationship we can derive that the relative change in concentration is inversely proportional to the relative change in ventilation $(\Delta C / C=-\Delta V / V)$. The concentration under-prediction at each location could therefore be corrected with a change in average surface wind speed of $\sim 0.15 \mathrm{~m} \mathrm{~s}^{-1}$ at the Sacramento (S13) site to $\sim 1.98 \mathrm{~m} \mathrm{~s}^{-1}$ at the Modesto (M13) site.

Panel (c) shows the measured and predicted annual average concentrations of $\mathrm{OC}$ at the six representative sites chosen for model evaluation. Measured annual average OC concentrations ranged from $5.5-8 \mu \mathrm{g} \mathrm{m}^{-3}$ while predicted OC concentrations range from $2.8-5.4 \mu \mathrm{g} \mathrm{m}^{-3}$. In short, OC con- centrations were under-estimated by $\sim 33-60 \%$ at all sites except for the San Jose (SJ4) and Central Los Angeles (CELA) sites where predictions match observations within $\sim 16 \%$. OC can either be emitted directly from sources (primary) or it can be produced in the atmosphere through precursor reactions that form products with low saturation vapor pressure (SOA). In the present study, $\sim 99 \%$ of the annual average OC concentrations was attributed to primary organic compounds with the remaining $\sim 1 \%$ attributed to SOA formation. Recent studies suggest that primary organic aerosol is semi-volatile (Huffman et al., 2009) implying that SOA formation dominates total $\mathrm{OC}$ formation but major questions remain unanswered concerning the exact composition and formation mechanism of this material. Mechanisms that depend on high concentrations of intermediate-volatility precursor compounds have been proposed (Presto et al., 2009), and even implemented in regional calculations (Robinson et 

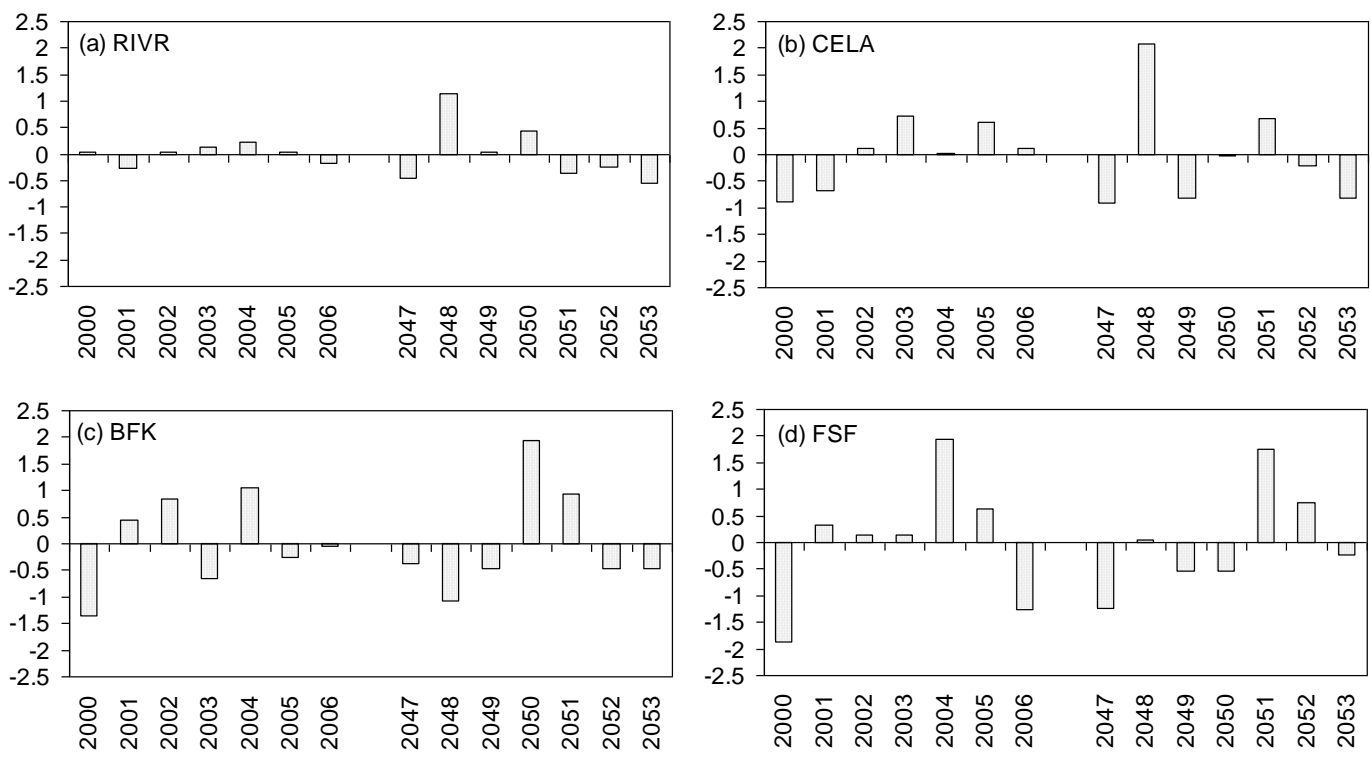

Present-day

Future

Present-day

Future

Fig. 5. Predicted variations around the 7-year average $\mathrm{PM}_{2.5}$ total mass concentration at four sites in California: (a) Riverside-Rubidoux (RIVR), (b) Central Los Angeles (CELA), (c) Bakersfield (BFK), and (d) Fresno (FSF).

al., 2007), but the intermediate volatility framework characterizes all compounds solely by their saturation vapor pressure. It therefore requires numerous parameterizations for critical elements (rate at which compounds transition between volatility bins, temperature dependence of partitioning, etc.) that (to date) are based on simplistic laboratory experiments. Much work remains to be done using additional laboratory experiments and retrospective field studies supported by comprehensive measurements to constrain these critical parameters before the intermediate volatility framework can be used confidently for climate-air quality predictions. More chemically complete models for SOA formation that include calculations for activity coefficients in aqueous and organic phases (Kleeman et al., 2007) have been shown to form roughly the same amount of SOA as more simplistic two product absorption models (Ying et al., 2007). The more computationally efficient two-product model was used in the current study, with the caveat that it does not completely describe all aspects of SOA formation.

Panels (d-f) show the measured and predicted annual average concentrations of $\mathrm{PM}_{2.5}$ nitrate, ammonium, and sulfate, respectively. The plots show that the model underpredicts the concentrations of secondary species at all the chosen monitoring sites by $\sim 18-73 \%$. The majority of this under-prediction is likely caused by the excess ventilation produced by the PCM-WRF meteorological predictions (see discussion for Fig. 4b) exacerbated by the non-linear chemical system for the formation of secondary PM (Aw and Kleeman, 2003). The pattern of variation between sites appears to be similar for the measured and predicted concentrations of secondary PM since model predictions are able to identify the sites with the highest and lowest concentrations of each secondary pollutant.

Natural annual and intra-annual variability makes it extremely difficult to quantify climate impacts on airborne particulate matter concentrations in California. Panels in Fig. 5 show the differences between predicted annual average $\mathrm{PM}_{2.5}$ concentrations and their 7-year averages at Riverside, central Los Angeles, Bakersfield, and Fresno over the periods 2000-2006 and 2047-2053. The relative standard deviations (standard deviation divided by the mean) are $2 \%$, $3 \%, 6 \%$ and $9 \%$ for the present (2000-2006), and 5\%, 6\%, $8 \%$ and $7 \%$ for the future (2047-2053) periods at Riverside, central Los Angeles, Bakersfield, and Fresno, respectively. This annual variability in $\mathrm{PM}_{2.5}$ mass concentrations is mainly caused by normal variation in yearly meteorology combined with ENSO effects. One of the key objectives in this study was to capture this annual variability both in the present (2000-2006) and future (2047-2053) air quality simulations so that the effects of global change can be understood over a climatologically relevant period.

The ENSO cycle is generally $\sim 3-8$-years, and so any effect from the ENSO cycle on air quality should to be present in a 7-year analysis period. The variation in a given year (shown in Fig. 5) is primarily due to natural intraannual/seasonal variations caused by the ENSO cycle. The El Niño phase of the ENSO cycle can be identified in California by increased winter precipitation. An analysis of 
(a) $\Delta$ Mass

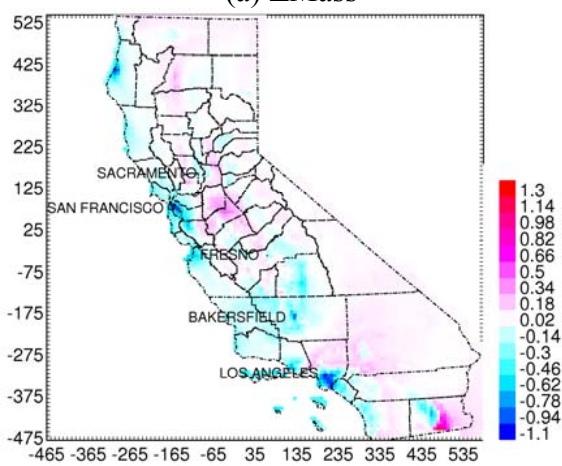

(c) $\triangle \mathrm{EC}$

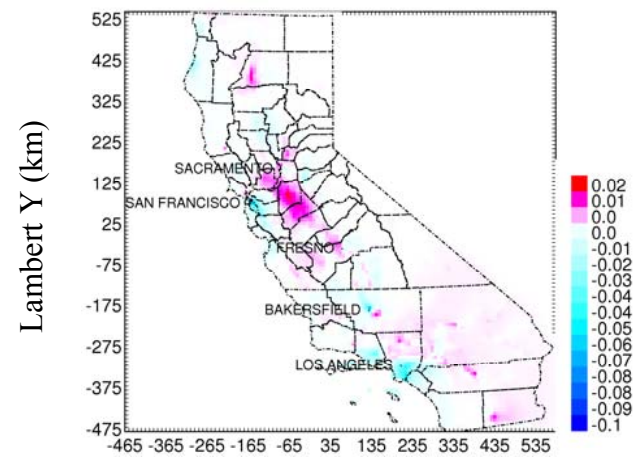

(e) $\triangle \mathrm{OC}$

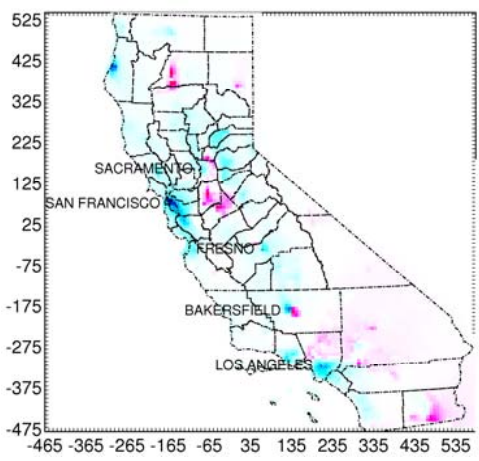

(b) p-value

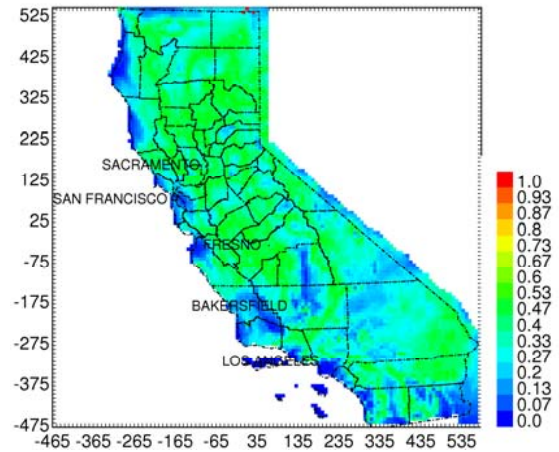

(d) p-value

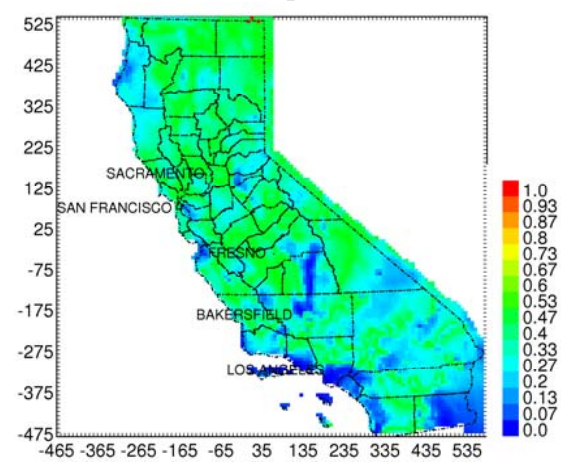

(f) p-value

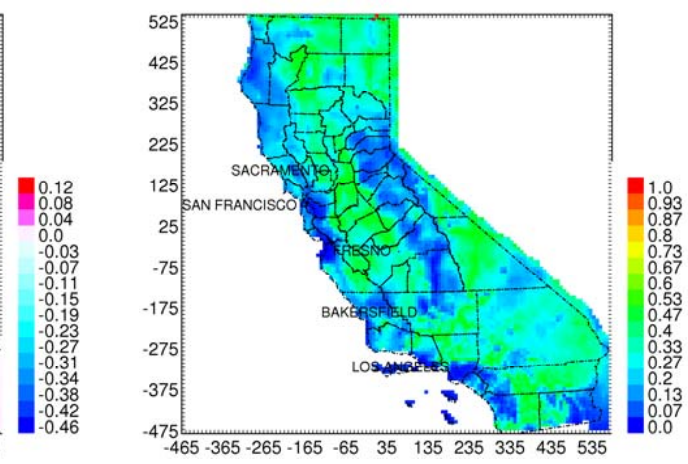

Lambert X $(\mathrm{km})$

Fig. 6. Changes in annual average total mass and primary $\mathrm{PM}_{2.5}$ concentrations, and their corresponding p-values in CA likely to occur in the future (2047-2053) due to climate change from the present-day (2000-2006). The p-value quantifies the likelihood that average future concentrations are equal to present day concentrations.

the rainfall data showed the year with the largest negative anomaly from the 7-year average had average precipitation rates that were $\sim 30 \%-90 \%$ greater than the 7 -year average, proving that this was indeed an ENSO effect.

The air quality simulations both in the present-day and future climate were carried out with present-day emissions for California. The differences between the future (20472053) and present-day (2000-2006) annual average concentrations of $\mathrm{PM}_{2.5}$ total mass, EC and $\mathrm{OC}$ are illustrated in Fig. 6. Panels (a, c, e) display the difference between the 7year averages while panels $(b, d, f)$ display the significance of this result expressed as the p-value. The p-value quanti- fies the likelihood that present day (2000-2006) concentrations and future (2047-2053) concentrations are equal. The p-value is calculated using information about the mean and variance within each 7-year window. Small p-values are produced when large differences exist between present and future concentrations while the annual variability of concentrations within the present and future analysis windows is small. The 7-year analysis windows used in the current study are long by atmospheric chemical modeling standards but relatively short by statistical standards and so p-values were calculated using the student $\mathrm{T}$ distribution with $6^{\circ}$ of freedom rather than the Normal distribution. 
Figure 6a shows that the future annual average $\mathrm{PM}_{2.5}$ mass concentration is predicted to increase by $\sim 0.2-0.5 \mu \mathrm{g} \mathrm{m}{ }^{-3}$ in the SV, and by $\sim 0.5 \mu \mathrm{g} \mathrm{m}^{-3}$ in some areas in the SJV. The corresponding p-values shown in panel (b) are $\geq 0.4$ indicating that these changes are small relative to the annual variability in the predicted signal. $\mathrm{PM}_{2.5}$ concentrations are predicted to decrease by $\sim 0.3-0.7 \mu \mathrm{g} \mathrm{m}^{-3}$ in the southern portion of the SJV and decrease by $\sim 0.3-1.1 \mu \mathrm{g} \mathrm{m}^{-3}$ along coastal regions of California including the heavily populated San Francisco Bay Area and the SoCAB surrounding Los Angeles. In fact, the model calculations do not predict significant changes (at the 95\% confidence level) in the $\mathrm{PM}_{2.5}$ concentrations anywhere in California except in small regions around coastal and central Los Angeles, and around the port of Oakland in the San Francisco Bay Area, where $\mathrm{PM}_{2.5}$ concentrations are predicted to decrease by $\sim 0.7-1.1 \mu \mathrm{g} \mathrm{m}^{-3}$. The corresponding p-value plot (panel b) indicates that these changes are large relative to the annual variability. As discussed previously, the majority of this decreased concentration stems from increased wind speeds and warmer temperatures providing greater ventilation of primary emissions and increased volatilization of secondary components. The increased wind speed is predicted largely because of the synoptic features of the GCM inputs that were used in the analysis. GCM calculations are usually employed to build confidence in the results of climate calculations. The present study provides a first data-point for a GCM-WRF-air quality model calculation of climate impacts on air quality that should be followed up with a full ensemble of downscaling runs using multiple GCMs as their starting point.

In general, the major features of the $\mathrm{PM}_{2.5}$ mass analysis illustrated in Fig. 6a, b are echoed for $\mathrm{PM}_{2.5}$ EC in Fig. 6c, $\mathrm{d}$ and for $\mathrm{PM}_{2.5} \mathrm{OC}$ in Fig. 6e, f. The only significant trends at the $95 \%$ confidence level are localized in a sub-region of Los Angeles where concentrations generally decrease due to the effects of increased ventilation. Future (2047-2053) annual average EC concentrations are predicted to decrease by $\sim 0.02-0.04 \mu \mathrm{g} \mathrm{m}^{-3}$ while future annual average OC concentrations are predicted to decrease by $\sim 0.10-0.30 \mu \mathrm{g} \mathrm{m}^{-3}$ in coastal and central Los Angeles relative to current conditions (2000-2006). The future annual average OC concentration in the San Francisco bay area will also decrease by $\sim 0.3-$ $0.5 \mu \mathrm{g} \mathrm{m}^{-3}$ due to climate change effect, which is significant at $95 \%$ confidence interval.

Figure 7 shows the predicted change in annual average concentrations for the secondary $\mathrm{PM}_{2.5}$ species and their corresponding p-values using the same format as Fig. 6. Patterns for nitrate and ammonium ion (panels a-d) are similar with $95 \%$ confidence achieved for reductions in the SoCAB, in the southern portion of the SJV and extending along the Pacific coast between LA and San Francisco. PM $_{2.5}$ nitrate concentrations are predicted to decrease in both of these regions by up to $0.26 \mu \mathrm{g} \mathrm{m}^{-3}$ with a corresponding decrease of $0.13 \mu \mathrm{g} \mathrm{m}^{-3}$ in ammonium ion concentrations. $\mathrm{PM}_{2.5}$ nitrate concentrations are predicted to increase in the northern
SJV and southern SV by up to $0.2 \mu \mathrm{g} \mathrm{m}^{-3}$ and in the eastern portion of the SoCAB by up to $0.15 \mu \mathrm{g} \mathrm{m}^{-3}$ with corresponding p-values $<0.1$ in portions of these regions. The majority of this increased nitrate concentration stems from the impact of higher background ozone concentrations in future years, which increases the rate of nitric acid production.

$\mathrm{PM}_{2.5}$ sulfate concentrations are predicted to decrease very slightly in northern CA and around central Los Angeles but increase slightly in the eastern portions of southern California. Each of these trends is significant at the $95 \%$ confidence level in portions of the domain. Sulfate increases result from increased temperatures that speed up oxidation of S(IV).

\section{Summary and conclusion}

The effect of global climate change on annual average $\mathrm{PM}_{2.5}$ mass concentrations in California has been studied using seven year analysis periods that allowed for meaningful statistical analysis of the results. A regional climate-air quality modeling system was employed that downscaled PCM output using the WRF model followed by emissions generation and air quality simulations using the UCD/CIT photochemical model to predict $\mathrm{PM}_{2.5}$ concentrations. Simulations were carried out for the present-day climate (2000-2006) and the future (2047-2053) under the "business as usual" global emissions scenario. Air pollutant emissions in California were held at their nominal year 2000 levels to directly examine the effect of climate on regional air quality.

The present-day results from the climate-air quality modeling system successfully predicted the spatial pattern of high $\mathrm{PM}_{2.5}$ concentrations in California but the absolute magnitude of the annual average $\mathrm{PM}_{2.5}$ concentrations were under-predicted by $\sim 4-39 \%$ at different sites in the major air basins. Of the total $\mathrm{PM}_{2.5}$ mass, primary $\mathrm{PM}$ concentrations were only under-estimated by $12-66 \%$ while secondary PM concentrations were under-estimated by $\sim 18$ $73 \%$. The majority of this under-prediction is likely caused by the excess ventilation produced by the PCM-WRF meteorological predictions that should be consistent in both present and future climate so that a minimum amount of net bias is introduced into the comparison (Zhao et al., 2010a). The present study is among the first to evaluate climate-air quality model performance over a climatologically relevant time-frame (7-year averages) using prognostic meteorology produced by a GCM. It is likely that other modeling systems would have similar performance features if they were checked against observations.

Future predictions indicate that changes to global climate lead to changes in key regional meteorological parameters that affect airborne particulate matter concentrations in California. An analysis of the major meteorological variables shows that the future surface temperature, relative humidity $(\mathrm{RH})$, rain rate, and wind speed are predicted to increase 
(a) $\Delta$ Nitrate

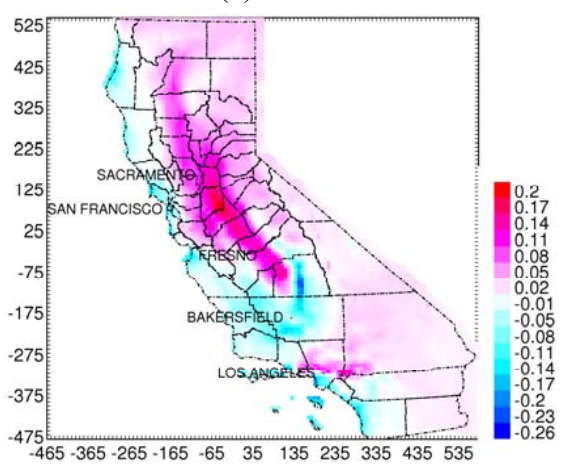

(c) $\Delta$ Ammonium

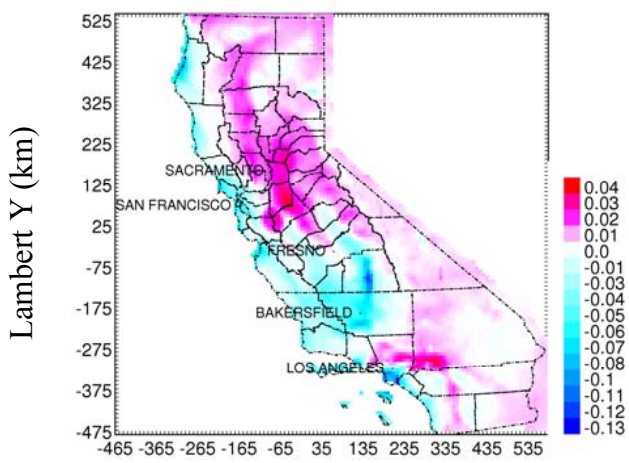

(e) $\Delta$ Sulfate

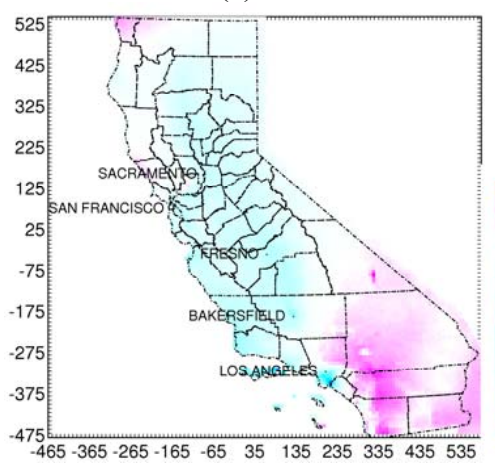

(b) p-value

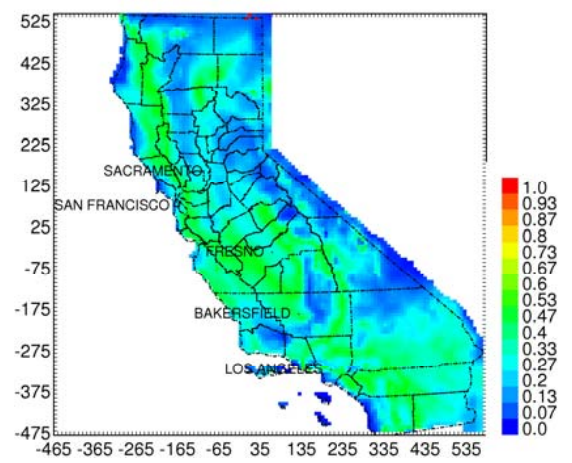

(d) p-value

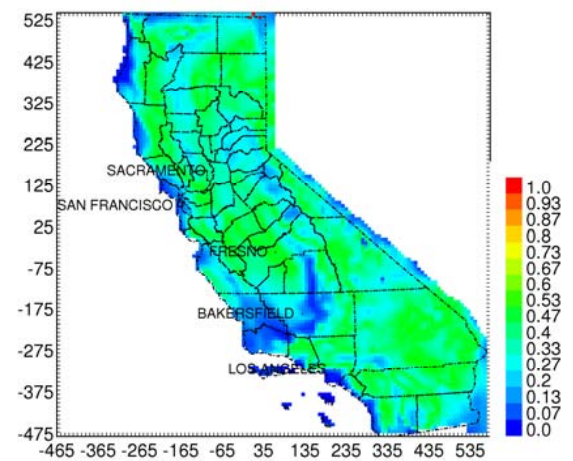

(f) p-value

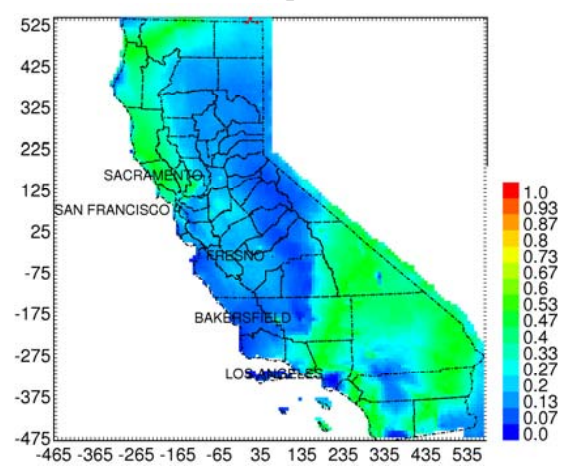

Lambert X (km)

Fig. 7. Changes in annual average secondary $\mathrm{PM}_{2.5}$ concentrations, and their corresponding p-values in CA likely to occur in the future (2047-2053) due to climate change from the present-day (2000-2006). The p-value quantifies the likelihood that average future concentrations are equal to present day concentrations.

while the UV radiation is predicted to decrease in major urban areas in the SJV and SoCAB. These changes lead to a significant decrease in predicted $\mathrm{PM}_{2.5}$ mass concentrations of $\sim 0.6-1.1 \mu \mathrm{g} \mathrm{m}^{-3}$ in small regions around coastal and central Los Angeles and around the port of Oakland in the heavily populated San Francisco Bay Area. The 95\% confidence interval spans zero for $\mathrm{PM}_{2.5}$ concentration changes in other parts of California. The natural annual variability in the $\mathrm{PM}_{2.5}$ predictions were larger than the changes induced by climate, suggesting that it may be necessary to include secondary feedback effects such as modification of cloud cover due to aerosol emissions in order to accurately predict cli- mate effects on PM concentrations. The dominance of interannual variability over long-term climate trends contradicts previous studies that have predicted decreased $\mathrm{PM}_{2.5}$ concentrations throughout California in response to climate change. Those previous studies used coarser spatial resolution and shorter averaging times that made it difficult to fully analyze geographical variation and annual variability in California. The $8 \mathrm{~km}$ spatial resolution combined with the 7-year analysis periods used in the current study provide the most comprehensive picture to date about climate effects on $\mathrm{PM}_{2.5}$ concentrations in California. 
GCM calculations have a certain degree of inherent uncertainty and so ensembles of GCM calculations are usually employed to build confidence in the results of climate calculations. The present study provides a first data-point for a GCM-WRF-air quality model calculation of climate impacts on air quality in California that should be followed up with a full ensemble of downscaling runs using multiple GCMs as their starting point. In particular, it would be interesting to determine if the pattern of temperature change over ocean vs. over land during the winter months would be consistent if a different GCM was used as the starting point. An investigation to answer this question is currently underway and the results will be reported separately.

Acknowledgements. This research was funded by the California Air Resources Board under Contract \# 04-349. The statements and conclusions of this Report are those of the contractor and not necessarily those of the California Air Resources Board. The mention of commercial products, their source, or their use in connection with material reported herein is not to be construed as actual or implied endorsement of such products.

Edited by: R. Vautard

\section{References}

Avise, J., Chen, J., Lamb, B., Wiedinmyer, C., Guenther, A., Salathé, E., and Mass, C.: Attribution of projected changes in summertime US ozone and $\mathrm{PM}_{2.5}$ concentrations to global changes, Atmos. Chem. Phys., 9, 1111-1124, doi:10.5194/acp9-1111-2009, 2009.

Aw, J. and Kleeman, M. J.: Evaluating the first-order effect of intraannual temperature variability on urban air pollution, J. Geophys. Res., 108(D12), 4365, doi:10.1029/2002JD002688, 2003.

Byun, D. W.: Dynamically consistent formulations in meteorological and air quality models for multiscale atmospheric studies, Part II: Mass conservation issues, J. Atmos. Sci., 56, 3808-3820, 1999.

Cerro, C., Codina, B., Bech, J., and Lorente, J.: Modeling raindrop size distribution and $\mathrm{Z}(\mathrm{R})$ relations in the Western Mediterranean area, J. Appl. Meteorol., 36, 1470-1479, 1997.

Chen, J., Avise, J., Lamb, B., Salathé, E., Mass, C., Guenther, A., Wiedinmyer, C., Lamarque, J.-F., O’Neill, S., McKenzie, D., and Larkin, N.: The effects of global changes upon regional ozone pollution in the United States, Atmos. Chem. Phys., 9, 11251141, doi:10.5194/acp-9-1125-2009, 2009.

Clegg, S. L., Kleeman, M. J., Griffin, R. J., and Seinfeld, J. H.: Effects of uncertainties in the thermodynamic properties of aerosol components in an air quality model - Part 1: Treatment of inorganic electrolytes and organic compounds in the condensed phase, Atmos. Chem. Phys., 8, 1057-1085, doi:10.5194/acp-81057-2008, 2008.

Dai, A., Wigley, T. M. L., Boville, B. A., Kiehl, J. T., and Buja, L. E.: Climates of the twentieth and twenty-first centuries simulated by the NCAR climate system model, J. Climate, 14, 485-519, $2001 \mathrm{a}$.

Dai, A., Meehl, G. A., Washington, W. M., Wigley, T. M. L., and Arblaster, J. M.: Ensemble simulation of twenty-first century cli- mate changes: Business-as-usual versus $\mathrm{CO}_{2}$ stabilization, $\mathrm{B}$. Am. Meteor. Soc., 82, 2377-2388, 2001b.

Dawson, J. P., Racherla, P. N., Lynn, B. H., Adams, P. J., and Pandis, S. N.: Impacts of climate change on regional and urban air quality in the eastern United States: Role of meteorology, J. Geophys. Res., 114, D05308, doi:10.1029/2008JD009849, 2009.

de Leeuw, G., Neele, F. P., Hill, M., Smith, M. H., and Vignali, E.: Production of sea spray aerosol in the surf zone, J. Geophys. Res. Atmos., 105, 29397-29409, 2000.

Dudhia, A.: Noise Characteristics of the Avhrr Infrared Channels, Int. J. Remote Sens., 10, 637-644, 1989.

Fountoukis, C. and Nenes, A.: ISORROPIA II: a computationally efficient thermodynamic equilibrium model for $\mathrm{K}^{+}{ }_{-} \mathrm{Ca}^{2+}-\mathrm{Mg}^{2+}{ }_{-} \mathrm{NH}_{4}{ }^{+}-\mathrm{Na}^{+}-\mathrm{SO}_{4}{ }^{2-}{ }_{-} \mathrm{NO}_{3}{ }^{-}-\mathrm{Cl}^{-}-\mathrm{H}_{2} \mathrm{O}$ aerosols, Atmos. Chem. Phys., 7, 4639-4659, doi:10.5194/acp7-4639-2007, 2007.

Gong, S. L.: A parameterization of sea-salt aerosol source function for sub- and super-micron particles, Global Biogeochem. Cy., 4, 1097, doi:10.1029/2003GB002079, 2003.

Grell, G. A. and Devenyi, D.: A generalized approach to parameterizing convection combining ensemble and data assimilation techniques, Geophys. Res. Lett., 29(14), 1693, doi:10.1029/2002GL015311, 2002.

Grell, G., Dudhia, J., and Stauffer, D. R.: A description of the fifth generation Penn State/NCAR mesoscale model (MM5), NCAR Tech. Note, NCAR/TN-398+STR, 1994.

Griffin, R. J., Dabdub, D., and Seinfeld, J. H.: Secondary organic aerosol - 1. Atmospheric chemical mechanism for production of molecular constituents, J. Geophys. Res., 107(D17), 4332, doi:10.1029/2001JD000541, 2002.

Halenka, T., Husar, P., and Belda, M.: Regional Climate Change Impacts on Air Quality in High Resolution, Air Pollution Modelling and Its Application XX, 515-523, doi:10.1007/978-90481-3812-8, 2010.

Harley, R. A., Russell, A. G., Mcrae, G. J., Cass, G. R., and Seinfeld, J. H.: Photochemical Modeling of the Southern California Air-Quality Study, Environ. Sci. Technol., 27, 378-388, 1993.

Held, T., Ying, Q., Kaduwela, A., and Kleeman, M.: Modeling particulate matter in the San Joaquin Valley with a source-oriented externally mixed three-dimensional photochemical grid model, Atmos. Environ., 38, 3689-3711, 2004.

Held, T., Ying, Q., Kleeman, M. J., Schauer, J. J., and Fraser, M. P.: A comparison of the UCD/CIT air quality model and the CMB source-receptor model for primary airborne particulate matter, Atmos. Environ., 39, 2281-2297, 2005.

Hogrefe, C., Lynn, B., Civerolo, K., Ku, J. Y., Rosenthal, J., Rosenzweig, C., Goldberg, R., Gaffin, S., Knowlton, K., and Kinney, P. L.: Simulating changes in regional air pollution over the eastern United States due to changes in global and regional climate and emissions, J. Geophys. Res., 109, D22301, doi:10.1029/2004JD004690, 2004.

Hong, S. Y., Dudhia, J., and Chen, S. H.: A revised approach to ice microphysical processes for the bulk parameterization of clouds and precipitation, Mon. Weather Rev., 132, 103-120, 2004.

Hong, S. Y., Noh, Y., and Dudhia, J.: A new vertical diffusion package with an explicit treatment of entrainment processes, Mon. Weather Rev., 134, 2318-2341, 2006.

Hu, Y. T., Odman, M. T., and Russell, A. G.: Mass conservation in the Community Multiscale Air Quality model, Atmos. Environ., 
40, 1199-1204, 2006.

Hu, J., Ying, Q., Chen, J., Mahmud, A., Zhao, Z., Chen, S.-H., and Kleeman, M. J.: Particulate Air Quality Model Predictions using Prognostic vs. Diagnostic Meteorology in Central California, Atmos. Environ., 44, 215-226, 2010.

Huffman, J. A., Docherty, K. S., Mohr, C., Cubison, M. J., U1brich, I. M., Ziemann, P. J., Onasch, T. B., and Jimenez, J. L.: Chemically-Resolved Volatility Measurements of Organic Aerosol from Different Sources, Environ. Sci. Technol., 43, 5351-5357, 2009.

Jacobson, M. Z.: A solution to the problem of nonequilibrium acid/base gas-particle transfer at long time step, Aerosol Sci. Technol., 39, 92-103, 2005.

Jacobson, M. Z.: On the causal link between carbon dioxide and air pollution mortality, Geophys. Res. Lett., 35, L03809, doi:10.1029/2007GL031101, 2008.

Jacobson, M. Z.: Enhancement of Local Air Pollution by Urban $\mathrm{CO}_{2}$ Domes, Environ Sci. Technol., 44, 2497-2502, doi:10.1021/es903018m, 2010.

Jaffe, D., Tamura, S., and Harris, J.: Seasonal cycle and composition of background fine particles along the west coast of the US, Atmos. Environ., 39, 297-306, 2005.

Kleeman, M. J.: A preliminary assessment of the sensitivity of air quality in California to global change, Clim. Change, 87, S273S292, 2008.

Kleeman, M. J. and Cass, G. R.: A 3-D Eulerian source-oriented model for an externally mixed aerosol, Environ. Sci. Technol., 35, 4834-4848, 2001.

Kleeman, M. J., Cass, G. R., and Eldering, A.: Modeling the airborne particle complex as a source-oriented external mixture, J. Geophys. Res. Atmos., 102(D17), 21355-21372, doi:10.1029/97JD01261, 1997.

Kleeman, M. J., Ying, Q., Lu, J., Mysliwiec, M. J., Griffin, R. J., Chen, J. J., and Clegg, S.: Source apportionment of secondary organic aerosol during a severe photochemical smog episode, Atmos. Environ., 41, 576-591, 2007.

Lee, S. M., Yoon, S. C., and Byun, D. W.: The effect of mass inconsistency of the meteorological field generated by a common meteorological model on air quality modeling, Atmos. Environ., 38, 2917-2926, doi:10.1016/j.atmosenv.2004.02.008, 2004.

Leung, L. R., Qian, Y., Bian, X. D., Washington, W. M., Han, J. G., and Roads, J. O.: Mid-century ensemble regional climate change scenarios for the western United States, Clim. Change, 62, 75113,2004

Liang, J. Y., Horowitz, L. W., Jacob, D. J., Wang, Y. H., Fiore, A. M., Logan, J. A., Gardner, G. M., and Munger, J. W.: Seasonal budgets of reactive nitrogen species and ozone over the United States, and export fluxes to the global atmosphere, J. Geophys. Res. Atmos., 103, 13435-13450, 1998.

Liang, X. Z., Pan, J. P., Zhu, J. H., Kunkel, K. E., Wang, J. X. L., and Dai, A.: Regional climate model downscaling of the US summer climate and future change, J. Geophys. Res. Atmos., 111, D10108, doi:10.1029/2005JD006685, 2006.

Liao, K.-J., Tagaris, E., Manomaiphiboon, K., Wang, C., Woo, J.H., Amar, P., He, S., and Russell, A. G.: Quantification of the impact of climate uncertainty on regional air quality, Atmos. Chem. Phys., 9, 865-878, doi:10.5194/acp-9-865-2009, 2009.

Loosmore, G. A. and Cederwall, R. T.: Precipitation scavenging of atmospheric aerosols for emergency response applications: test- ing an updated model with new real-time data, Atmos. Environ., 38, 993-1003, 2004.

Martien, P. T. and Harley, R. A.: Adjoint sensitivity analysis for a three-dimensional photochemical model: Application to Southern California, Environ. Sci. Technol., 40, 4200-4210, 2006.

Mcrae, G. J., Goodin, W. R., and Seinfeld, J. H.: Development of a 2nd-Generation Mathematical-Model for Urban Air-Pollution .1. Model Formulation, Atmos. Environ., 16, 679-696, 1982.

Menut, L., Coll, I., and Cautenet, S.: Impact of meteorological data resolution on the forecasted ozone concentrations during the ESCOMPTE IOP2a and IOP2b, Atmos. Res., 74, 139-159, 2005.

Mlawer, E. J., Taubman, S. J., Brown, P. D., Iacono, M. J., and Clough, S. A.: Radiative transfer for inhomogeneous atmospheres: RRTM, a validated correlated-k model for the longwave, J. Geophys. Res. Atmos., 102, 16663-16682, 1997.

Mysliwiec, M. J. and Kleeman, M. J.: Source apportionment of secondary airborne particulate matter in a polluted atmospbere, Environ. Sci. Technol., 36, 5376-5384, 2002.

Nenes, A., Pandis, S. N., and Pilinis, C.: ISORROPIA: A new thermodynamic equilibrium model for multiphase multicomponent inorganic aerosols, Aquat. Geochem., 4, 123-152, 1998.

Odman, M. T. and Russell, A. G.: Mass conservative coupling of non-hydrostatic meteorological models with air quality models, in: Air Pollution Modeling and its Application XIII, edited by: Gryning, S. E. and Batchvarova, E., Kluwer/Plenum, New York, 651-660, 2000.

Pope, C. A.: Review: Epidemiological basis for particulate air pollution health standards, Aerosol Sci. Technol., 32, 4-14, 2000.

Presto, A. A., Miracolo, M. A., Kroll, J. H., Worsnop, D. R., Robinson, A. L., and Donahue, N. M.: Intermediate-Volatility Organic Compounds: A Potential Source of Ambient Oxidized Organic Aerosol, Environ. Sci. Technol., 43, 4744-4749, 2009.

Robinson, A. L., Donahue, N. M., Shrivastava, M. K., Weitkamp, E. A., Sage, A. M., Grieshop, A. P., Lane, T. E., Pierce, J. R., and Pandis, S. N.: Rethinking organic aerosols: Semivolatile emissions and photochemical aging, Science, 315, 1259-1262, 2007.

Russell, G. L., Miller, J. R., and Rind, D.: A coupled atmosphere ocean model for transient climate change studies, Atmos. Ocean, 33, 683-673, 1995.

Sillman, S. and Samson, F. J.: Impact of Temperature on Oxidant Photochemistry in Urban, Polluted Rural and Remote Environments, J. Geophys. Res.-Atmos., 100, 11497-11508, 1995.

Skamarock, W. C.: Evaluating mesoscale NWP models using kinetic energy spectra, Mon. Weather Rev., 132, 3019-3032, 2004

Sportisse, B., Quelo, D., and Mallet, V.: Impact of mass consistency errors for atmospheric dispersion, Atmos. Environ., 41, 61326142, 2007.

Tagaris, E., Manomaiphiboon, K., Liao, K. J., Leung, L. R., Woo, J. H., He, S., Amar, P., and Russell, A. G.: Impacts of global climate change and emissions on regional ozone and fine particulate matter concentrations over the United States, J. Geophys Res., 112, D14312, doi:10.1029/2006JD008262, 2007.

Tagaris, E., Liao, K. J., Delucia, A. J., Deck, L., Amar, P., and Russell, A. G.: Potential Impact of Climate Change on Air PollutionRelated Human Health Effects, Environ. Sci. Technol., 43, 49794988, 2009.

Tran, H. T., Alvarado, A., Garcia, C., Motallebi, N., Miyasato, L., and Vance, W.: Methodology for Estimating Premature Deaths Associated with Long-term Exposure to Fine Airborne Partic- 
ulate Matter in California, California Environmental Protection Agency, Air Resources Board, Sacramento, CA, 2008.

Washington, W. M., Weatherly, J. W., Meehl, G. A., Semtner, A. J., Bettge, T. W., Craig, A. P., Strand, W. G., Arblaster, J., Wayland, V. B., James, R., and Zhang, Y.: Parallel climate model (PCM) control and transient simulations, Clim. Dynam., 16, 755-774, 2000.

Wexler, A. S. and Seinfeld, J. H.: Analysis of Aerosol AmmoniumNitrate - Departures from Equilibrium during Scaqs, Atmos. Environ. A-Gen., 26, 579-591, 1992.

Ying, Q. and Kleeman, M. J.: Effects of aerosol UV extinction on the formation of ozone and secondary particulate matter, Atmos. Environ., 37, 5047-5068, 2003.

Ying, Q. and Kleeman, M. J.: Source contributions to the regional distribution of secondary particulate matter in California, Atmos. Environ., 40, 736-752, 2006.
Ying, Q., Fraser, M. P., Griffin, R. J., Chen, J. J., and Kleeman, M. J.: Verification of a source-oriented externally mixed air quality model during a severe photochemical smog episode, Atmos. Environ., 41, 1521-1538, 2007.

Ying, Q., Lu, J., Allen, P., Livingstone, P., Kaduwela, A., and Kleeman, M. J.: Modeling air quality during the California Regional $\mathrm{PM}_{10} / \mathrm{PM}_{2.5}$ Air Quality Study (CRPAQS) using the UCD/CIT source-oriented air quality model - Part I: Base case model results, Atmos. Environ., 42, 8954-8966, 2008.

Zhao, Z., Chen, S.-H., Kleeman, M. J., Tyree, M., and Cayan, D.: The impact of climate change on air quality related meteorological conditions in California - Part I: Present time simulation analysis, J. Climate, under review, 2010a.

Zhao, Z., Chen, S.-H., and Kleeman, M. J.: The impact of climate change on air quality related meteorological conditions in California - Part II: Present versus future time simulation analysis, J. Climate, under review, 2010b. 